Studia Judaica 23 (2020), nr 2 (46), s. 309-356

doi:10.4467/24500100STJ.20.015.13658

Teresa Klimowicz (iD https://orcid.org/0000-0002-4383-2347

\title{
Nowy cmentarz żydowski w Lublinie jako palimpsest pamięci
}

\author{
THE NEW JEWISH CEMETERY IN LUBLIN AS A PALIMPSEST OF MEMORY
}

\begin{abstract}
The article seeks to understand the current condition of the new Jewish cemetery in Lublin, Poland. While it briefly presents the prewar history of the cemetery, the focus of the paper is on the afterwar period 1944-1992. The cemetery becomes a palimpsest of memory researched through activities, documents, media reports, and transformations of the area. The activities of Jewish organizations both in Poland and abroad, as well as activities of the local municipality create an image of both neglect and celebration. The specific situation of the cemetery as a functioning burial area is also explained in the context of politics and memory, as well as the general condition of the Jewish community in communist Poland.
\end{abstract}

Keywords: Lublin, Jewish cemetery, memory, Jewish heritage, Sara and Manfred Frenkel Foundation, Polish People's Republic.

Słowa kluczowe: Lublin, cmentarz żydowski, pamięć, dziedzictwo żydowskie, Fundacja Sary i Manfreda Frenklów, PRL.

\section{Wprowadzenie}

Los cmentarzy żydowskich w okresie powojennym pozostaje nadal mało zbadanym tematem. Istnieje wiele monografii poświęconych poszczególnym nekropoliom żydowskim, jednak w przeważającej mierze koncentrują się one na dziejach przedwojennych oraz opracowaniu treści i estetyki zachowanych nagrobków ${ }^{1}$. Celem niniejszego artykułu jest nie tylko rekon-

${ }^{1}$ Ukazało się wiele monografii na temat poszczególnych cmentarzy w różnych regionach Polski autorstwa m.in. Jana Jagielskiego i Moniki Krajewskiej, Leszka Hońdy, Marci- 
strukcja powojennych dziejów cmentarza przy ul. Walecznych w Lublinie, lecz także próba pokazania go jako swoistego „palimpsestu pamięci”, a zatem odczytania znaczeń, jakie niosła ze sobą omawiana przestrzeń dla poszczególnych podmiotów zaangażowanych w jej przekształcanie, upamiętnianie i destrukcję. Tym samym jest to próba odpowiedzi na pytanie o współczesną kondycję tej nekropolii.

Problem stanu zachowania cmentarzy żydowskich nie jest ani nowy, ani typowo powojenny. Po Zagładzie jednak temat tzw. mienia opuszczonego, do którego zaliczano również żydowskie nekropolie, nabrał nowego wymiaru i stał się problematyczny także ze względu na status prawny przyznany powojennym organizacjom żydowskim (chodzi tu przede wszystkim o brak ciągłości prawnej między przedwojennymi gminami wyznaniowymi i ich powojennymi odpowiednikami).

Problemy organizacyjne społeczności żydowskiej w ogóle odbijały się także na kondycji cmentarzy żydowskich. Fakt jednoczesnej działalności, a czasem rywalizacji, dwóch krajowych instytucji żydowskich - Centralnego Komitetu Żydów w Polsce (od roku 1950 przekształconego w Towarzystwo Społeczno-Kulturalne Żydów w Polsce) i Związku Religijnego Wyznania Mojżeszowego - oraz dwóch instytucji zagranicznych sprawiał, że nie było jasnego podziału kompetencji w zakresie utrzymania i ochrony nekropolii żydowskich w kraju.

Od 1944 r. na terenie Polski funkcjonowała reprezentacja społeczności żydowskiej w postaci Centralnego Komitetu Żydów w Polsce (CKŻP). Jednak w 1945 r. Ministerstwo Administracji Publicznej wydało Okólnik nr 3 z 6 lutego 1945 roku o tymczasowym uregulowaniu spraw wyznaniowych ludności żydowskiej². W dokumencie tym wprawdzie kategorycznie odrzucono możliwość tworzenia gmin wyznaniowych żydowskich nawiązujących do zasad funkcjonowania obowiązujących w okresie przedwojennym, lecz zezwolono na tworzenie nowych organizacji żydowskich. Powstał już wtedy swego rodzaju podział na CKŻP, które było organizacją o charakterze świeckim i społecznym, oraz Żydowskie Zrzeszenia

na Wodzińskiego i Jerzego Woronczaka. Tu warto wymienić opracowania Andrzeja Trzcińskiego i Pawła Sygowskiego dotyczące regionu lubelskiego: Andrzej Trzciński, Cmentarz żdowski w Hrubieszowie. Nagrobki niewykorzystane do pomnika-lapidarium i zakopane obok lapidarium, Lublin 1999; tenże, Świadkiem jest ta stela. Stary cmentarz żydowski w Lublinie, Lublin 2017; Paweł Sygowski, Cmentarze żydowskie Zamojszczyzny - stan badań, stan zachowania, uwagi konserwatorskie, [w:] Żydzi w Zamościu i na Zamojszczyźnie. Historia kultura - literatura, red. Weronika Litwin, Monika Szabłowska-Zaremba, Sławomir Jacek Żurek, Lublin 2012.

2 Dziennik Urzędowy Ministerstwa Administracji Publicznej nr 1 z 1945 r. 
Religijne (od czerwca 1946 r. - Żydowskie Kongregacje Wyznaniowe) po przekształceniach funkcjonujące jako Związek Religijny Wyznania Mojżeszowego - odpowiedzialne za działalność wyznaniową. Niejasny status prawny tej nowej organizacji o charakterze religijnym miał na celu ułatwienie przejęcia nad nią kontroli oraz skłonienie jej członków do przystąpienia do CKŻP. Efektem takiej polityki unifikacji społeczności żydowskiej, nasilającej się od roku 1948, była likwidacja relatywnie niezależnego CKŻP oraz ustanowienie Towarzystwa Społeczno-Kulturalnego Żydów w Polsce (TSKŻ) w 1950 r.

W tych przekształceniach częściowo brała udział także wspomniana Kongregacja Wyznaniowa, która jednak ostatecznie zachowała autonomię i niezależne od TSKŻ struktury. Warto podkreślić, że w myśl regulacji państwowych to właśnie ta organizacja - jako odpowiedzialna za sprawy wyznaniowe - miała być władna występować o udostępnienie obiektów o charakterze sakralnym (w tym cmentarzy). Praktyka wykazywała jednak, że administracja publiczna nie orientowała się w zawiłościach organizacji żydowskich i rozstrzygała sprawy na podstawie opinii członków TSKŻ. Brak jasno określonego podmiotu odpowiedzialnego za zachowanie cmentarzy oraz posiadającego środki na ten cel skutkował systematycznym pogarszaniem stanu ich zachowania.

Sprawę komplikowało również istnienie zagranicznych podmiotów żydowskiego życia społecznego zainteresowanych sytuacją w Polsce. Chodzi przede wszystkim o American Jewish Joint Distribution Committee oraz tzw. landsmanschafty (ziomkostwa), czyli działające poza granicami kraju organizacje zrzeszające Żydów pochodzących z danej miejscowości na terenie Polski. Ich zaangażowanie, choć stanowiące realne wsparcie dla wielu osób, prowadziło także do pogłębienia problemu z jednoznacznym wskazaniem podmiotu odpowiedzialnego za stan żydowskich nekropolii.

Ponadto polityka władz państwowych wobec społeczności żydowskiej zmieniała się w poszczególnych dekadach, co pociągało za sobą skutki znaczące także dla stanu zachowania cmentarzy żydowskich.

Przedstawiona w niniejszym artykule analiza dziejów lubelskiego cmentarza służy odtworzeniu powojennych dyskursów pamięci w okresie PRL. W nawiązaniu do przedstawionej przez Clifforda Geertza metody tzw. opisu gęstego ${ }^{3}$ interpretowane są znaczenia i motywy działań prowadzonych przez podmioty zaangażowane w przestrzeń cmentarza. Metoda ta umoż-

\footnotetext{
${ }^{3}$ Clifford Geertz, Opis gęsty - w stronę interpretatywnej teorii kultury, [w:] Badanie kultury. Elementy teorii antropologicznej, red. Marian Kempny, Ewa Nowicka, Warszawa 2005, s. 44.
} 
liwia traktowanie jako źródeł historycznych (i jako znaczących w ramach danego kontekstu kulturowego) nie tylko tradycyjnych dokumentów i zapisów administracyjnych, lecz także narracji prasowych, wspomnień, ikonografii czy przestrzeni samego cmentarza ${ }^{4}$. Przyjmuje się więc, że procesy społeczne i polityczne powiązane z nowym cmentarzem żydowskim w Lublinie są przykładami zachodzących przemian, które - w myśl koncepcji o cmentarzu jako „tekście kultury” - odzwierciedlają znaczenia związane z działaniami aktorów społecznych, ze statusem społeczności żydowskiej oraz kształtowaniem krajobrazu pamięci społecznej. Opowieść o losie cmentarzy to zarazem opowieść o Polakach i polskiej polityce, nie tylko historycznej, lecz także tożsamościowej. Przestrzeń cmentarzy żydowskich jest bowiem, jak pisał Konrad Matyjaszek, „lustrem, w którym przeglądają się Polacy, względem którego kształtują swój własny wizerunek, swoją tożsamość, swoje dobre imię i swoje narodowe przymioty"6. Nowy cmentarz żydowski w Lublinie jest zatem traktowany tutaj jako przykład „produkcji przestrzeni żydowskiej”, jako palimpsest reprezentujący zmiany kulturowego znaczenia specyficznej przestrzeni, jaką jest cmentarz w ogóle, a cmentarz żydowski w szczególności.

\section{Stan badań nad nowym cmentarzem żydowskim w Lublinie}

Szerzej zakrojone badania nad stanem żydowskich nekropolii zaczęto prowadzić dopiero w latach osiemdziesiątych XX w. Opracowania te powstawały jednak w pewnego rodzaju naukowej i świadomościowej „pustce” i miały w zasadzie prekursorski charakter.

Na uwage zasługuje dokonany przez Kazimierza Urbana i opatrzony obszernym komentarzem wybór materiałów dotyczących prawnego statusu synagog i cmentarzy żydowskich w Polskiej Rzeczypospolitej Ludowej. Centralnym dla powyższego opracowania problemem prawnych uregulowań stanu własności, zachowania i użytkowania przedwojennych nekropolii

\footnotetext{
${ }^{4}$ Por. Agnieszka Jagodzińska, Pomiędzy. Akulturacja Żydów Warszawy w drugiej połowie XIX wieku, Wrocław 2008, s. 15-17.

5 Termin wprowadzony przez Jacka Kolbuszewskiego - por. Jacek Kolbuszewski, Cmentarz jako tekst kultury, „Odra” (1981), nr 11, s. 31.

${ }^{6}$ Konrad Matyjaszek, Produkcja przestrzeni żydowskiej w dawnej i wspótczesnej Polsce, Kraków 2019, s. 9.

7 Tamże, s. 20.

${ }^{8}$ Kazimierz Urban, Cmentarze żydowskie, synagogi $i$ domy modlitwy $w$ Polsce $w$ latach 1944-1966 (wybór materiałów), Kraków 2006.
} 
zajmuje się również wydana w roku 2020 książka Małgorzaty Bednarek Sytuacja prawna cmentarzy żydowskich w Polsce 1944-20199. Warto wspomnieć też o zagranicznych opracowaniach Yechiela Weizmana ${ }^{10}$ dotyczących powojennych losów nekropolii żydowskich, ich statusu prawnego i kulturowego. Choć w ostatnich latach pojawiło się (głównie nakładem Żydowskiego Instytutu Historycznego ${ }^{11}$ ) kilka publikacji dotyczących życia i funkcjonowania społeczności żydowskiej w okresie PRL, kontekst historyczno-społeczny żydowskich nekropolii w tym okresie pozostaje nadal obszarem badawczo nieodkrytym. Ogromnym przełomem w tym zakresie jest wydana w połowie roku 2020 książka Krzysztofa Bielawskiego Zagłada cmentarzy żydowskich ${ }^{12}$, zbiorczo przedstawiająca proces destrukcji cmentarzy także w okresie PRL. Spośród lubelskich nekropolii żydowskich jak dotąd rzetelnego opracowania doczekał się jedynie - najcenniejszy i najlepiej zachowany - stary cmentarz żydowski przy ul. Siennej i ul. Kalinowszczyzna, opisany szczegółowo w niedawno opublikowanym, monumentalnym dziele Andrzeja Trzcińskiego ${ }^{13}$. Nowy cmentarz żydowski w Lublinie do tej pory był opisywany przede wszystkim w rozmaitych folderach i ulotkach na potrzeby turystyki. Podstawowe informacje na jego temat można też odnaleźć na specjalistycznych portalach internetowych, głównie dzięki działalności Krzysztofa Bielawskiego ${ }^{14}$. W roku 1987 próbę stworzenia historycznego opracowania żydowskiej nekropolii przy ul. Walecznych podjął Krzysztof Marciszuk na zlecenie Biura

${ }^{9}$ Małgorzata Bednarek, Sytuacja prawna cmentarzy żydowskich w Polsce 1944-2019, Kraków-Budapeszt 2020.

${ }^{10}$ Yechiel Weizman, The Sacralization and Secularization of Jewish Cemeteries in Poland, [w:] Jews and Non-Jews: Memories and Interactions from the Perspective of Cultural Studies, red. Lucyna Aleksandrowicz-Pędich, Jacek Partyka, Warszawa 2014, s. 205-220; tenże, Unsettled Possession: The Question of Ownership of Jewish Sites in Poland after the Holocaust from a Local Perspective, „Jewish Culture and History” 18 (2017), nr 1, s. 34-53.

${ }^{11}$ M.in.: August Grabski, Centralny Komitet Żydów w Polsce (1944-1950). Historia polityczna, Warszawa 2015; Piotr Kendziorek, Program i praktyka produktywizacji Żydów polskich w działalności CKŻP, Warszawa 2016; Helena Datner, Po Zagładzie. Społeczna historia żydowskich domów dziecka, szkót, kót studentów w dokumentach Centralnego Komitetu Żydów w Polsce, Warszawa 2016.

${ }^{12}$ Krzysztof Bielawski, Zagłada cmentarzy żydowskich, Warszawa 2020.

13 Trzciński, Świadkiem jest ta stela...

14 Zob. Krzysztof Bielawski, Lublin - nowy cmentarz żydowski, www.kirkuty.xip.pl/lublinnowy.htm [dostęp: 25 stycznia 2020]; Nowy cmentarz żydowski w Lublinie, https://sztetl. org.pl/pl/miejscowosci/l/264-lublin [dostęp: 25 stycznia 2020]; Baza danych nagrobków cmentarzy żydowskich w Polsce, Fundacja Dokumentacji Cmentarzy Żydowskich w Polsce, https://cemetery.jewish.org.pl/list/c_56 [dostęp: 4 listopada 2019]. 
Dokumentacji Zabytków ${ }^{15}$. W 2019 r. ukazała się także praca autorstwa Ireny Kowalczyk traktująca zbiorczo lubelskie nekropolie. Autorka opisała w niej krótko historię omawianego cmentarza, skupiając się na stanie jego zachowania i biografiach pogrzebanych tam i zidentyfikowanych osób $^{16}$. Jak dotąd cmentarz przy ul. Walecznych nie doczekał się jednak kompletnej monografii, brakuje zbiorczej analizy zarówno jego przedwojennych, jak i powojennych dziejów. Niniejszy artykuł stanowi przyczynek do rozwinięcia tego tematu na przykładzie nowego cmentarza żydowskiego w Lublinie, analizowanego nie tylko jako odzwierciedlenie losu społeczności żydowskiej, lecz jako pewną semantyczną całość, znaczącą także dla otoczenia jako miejsce performatywnego działania rozmaitych podmiotów uwikłanych w jego los.

\section{Topografia nowego cmentarza żydowskiego przy ul. Walecznych w Lublinie}

Na wstępie należy zaznaczyć, że przedmiotem zainteresowania w tym artykule jest obszar całego przedwojennego terenu lubelskiego cmentarza żydowskiego przy ul. Walecznych (dawniej ul. Unickiej) w jego najszerszym zasięgu. Zrozumienie topografii tej przestrzeni wymaga jednak wyjaśnienia. Po pierwsze - do tego kompleksu cmentarnego zaliczany jest także cmentarz wojenny z 1918 r. przylegający do jego południowej części. Po drugie - czynny cmentarz żydowski, użytkowany od 1944 r., znajduje się na obszarze funkcjonującym już przed wojną jako miejsce pochówków, ale nie obejmuje całego przedwojennego terenu nekropolii. Czynna, powojenna część nekropolii stanowi obszar wydzielony w ramach południowej części grzebalnej przedwojennego cmentarza oraz części cmentarza wojennego z 1918 r. Ponadto od lat siedemdziesiątych XX w. teren cmentarza jest przedzielony arterią komunikacyjną (al. Generała Władysława Andersa), która biegnie przez obszar przedwojennej nekropolii, dzieląc ją na część południową (gdzie znajduje się czynny cmentarz wyznaniowy) oraz północną (użytkowaną jako skwer). Przedmiotem niniejszego opracowania jest więc cały obszar przedwojennego cmentarza żydowskiego w latach 1944-1992 traktowany jako palimpsest reprezentujący powojenną politykę i pamięć o dziedzictwie żydowskim (il. 1).

${ }^{15}$ Krzysztof Marciszuk, Cmentarz żydowski przy ul. Walecznych w Lublinie, 1987, Archiwum Wojewódzkiego Urzędu Ochrony Zabytków w Lublinie [dalej: AWUOZ], sygn. 1239.

${ }^{16}$ Irena Kowalczyk, Lubelskie nekropolie, Lublin 2019. 


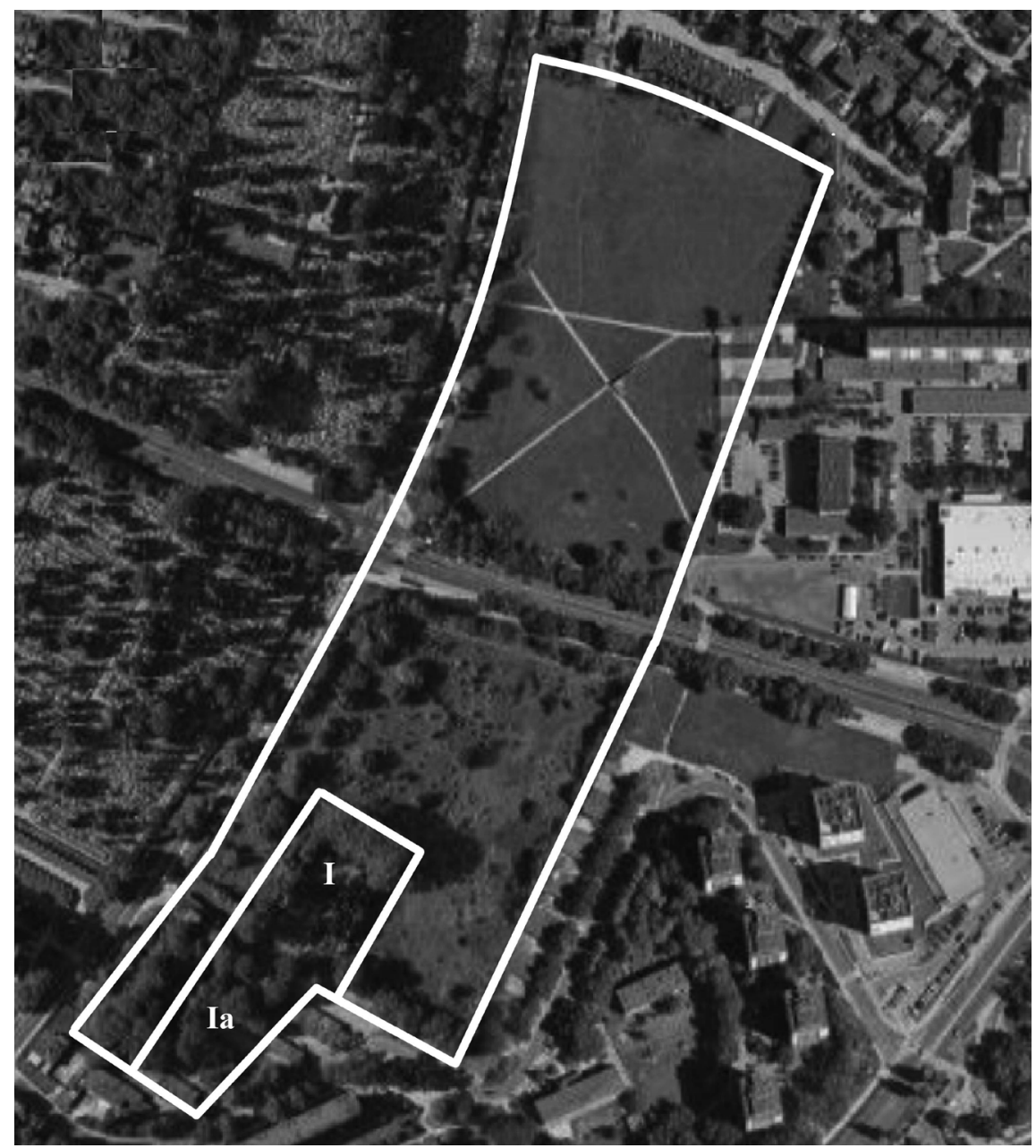

Il. 1. Mapa Google z orientacyjnie zaznaczonym maksymalnym zasięgiem cmentarza żydowskiego przy ul. Walecznych w Lublinie, https://www.google.com/maps/place/ Lublin. W jego obrębie wyróżniono część grzebalną (I) oraz dawny cmentarz wojenny (Ia) połączony z grzebalną częścią cmentarza. 


\section{Zarys historii cmentarza}

Nowy cmentarz żydowski w Lublinie został założony w $1828 \mathrm{r}$. w wyniku regulacji prawnych sytuujących cmentarze poza miastem ${ }^{17}$ oraz w związku z przepełnianiem się wspomnianego starego cmentarza ${ }^{18}$. Pierwsze pochówki odbyły się jednak dopiero w latach trzydziestych XIX w. z powodu dalszego użytkowania cmentarza przy ul. Siennej. Teren cmentarza kilkukrotnie rozszerzano, dokupując kolejne działk $\mathrm{i}^{19}$ od strony północnej, tak że ok. 1932 r. obszar nekropolii miał obejmować $86428 \mathrm{~m}^{2}$. W roku $1915^{20}$ lub $1918^{21}$ założony został żydowski cmentarz wojenny od południowej strony cmentarza gminnego. Ciała zostały ekshumowane w $1918 \mathrm{r}$. i sprowadzone na specjalnie utworzony cmentarz, przylegający do nowej nekropolii przy ul. Unickiej. Liczbę pochówków oszacowano ${ }^{22}$ na 164. Cmentarz ten spełniał istotną funkcję w podkreślaniu udziału Żydów w I wojnie światowej oraz ich zaangażowania w budowę niepodległego państwa polskiego. Był też ważnym elementem uroczystych obchodów rocznicy odzyskania niepodległości 11 listopada $^{23}$.

Nowy cmentarz żydowski funkcjonował także w czasie II wojny światowej. Wiosną $1940 \mathrm{r}$. teren cmentarza powiększono ${ }^{24}$ o 2 ha od północnej strony. Z zachowanego planu powstałej w 1940 r. części cmentarza wynika, że przyłączona działka miała kształt prostokąta, była użytkowana do celów

17 Przeniesienie miejsc pochówku poza miasta stało się obowiązkowe w 1792 r., kiedy Komisja Policji Obojga Narodów wydała specjalne zarządzenie pt. „Uniwersał do Miast Wolnych względem cmentarzy i szlachtuzów”, por. Jacek Dziobek-Romański, Cmentarze zarys regulacji historycznych, prawnych i kanonicznych, „Rocznik Historyczno-Archiwalny” 13 (1999), s. 10 i n.

${ }^{18}$ Brak miejsca na starym cmentarzu przy ul. Siennej rozwiązywano poprzez nasyp nowej warstwy ziemi już w XVII w., co pozwoliło przedłużyć okres jego użytkowania do $1830 \mathrm{r}$. Por. Trzciński, Świadkiem jest ta stela ..., s. 61-62.

${ }^{19}$ Lublin on a bejs-ojlem. Niszto szojn wu kejwer cu zajn mes, „Lubliner Tugblat” (9 października 1931), por.: Adam Kopciowski, Wos hert zich in der prowinc? Prasa żydowska na Lubelszczyźnie i jej największy dziennik „Lubliner Tugblat”, Lublin 2015, s. 357-358; Żydzi lubelscy $i$ ich cmentarze, [ulotka nieznanego autorstwa], Ośrodek „Brama Grodzka - Teatr NN" [dalej: OBGTNN], Archiwum Hanny Wyszkowskiej, teczka V, b.p.

${ }^{20}$ Konrad Zieliński, $W$ cieniu synagogi. Obraz życia kulturalnego społeczności żydowskiej Lublina w latach okupacji austro-węgierskiej, Lublin 1998, s. 71.

${ }^{21}$ Paweł Sygowski, Karta ewidencyjna cmentarza wojskowego przy ul. Walecznych / ul. J. Kuronia, nr 154, AWUOZ, Lublin 2019.

${ }^{22}$ Kopciowski, Wos hert sich..., s. 408-409.

23 Tamże, s. 409.

${ }^{24}$ Archiwum Państwowe w Lublinie [dalej: APL], Rada Żydowska w Lublinie [dalej: RŻL], sygn. 6/177, s. 1, 30 . 
grzebalnych od września tego roku ${ }^{25} \mathrm{i}$ miała przylegać do ul. Franciszkańskiej ${ }^{26}$. W literaturze przyjmuje się, że cmentarz ten był miejscem masowych egzekucji oraz grzebania zmarłych mieszkańców getta na Podzamczu ${ }^{27}$, wydaje się jednak, iż problem ten wymaga osobnych badań. Od 1 września 1939 r. do 1 października 1940 r. odnotowano 1214 zgonów i pogrzebów oraz wydano 1010 pozwoleń na postawienie pomników nagrobnych ${ }^{28}$. Pochówki w tym okresie odnotowywano od września 1940 r., a na nowej, przyłączonej w 1940 r. części - od stycznia 1941 r. Na jednej z nich (bliżej nieokreślonej) pochowano także ofiary działań wojennych z września 1939 r., ekshumowane 4 listopada tegoż roku z grobu w pobliżu szosy kraśnickiej ${ }^{29}$. Zgodnie ze stanem oznaczonym na zachowanym planie z sierpnia $1941 \mathrm{r}$. pochowano tam sześciu mężczyzn i dwie kobiety ${ }^{30}$. Na terenie cmentarza grzebano też ofiary getta lubelskiego ${ }^{31}$. W trakcie akcji likwidacyjnej w marcu i kwietniu $1942 \mathrm{r}$. bractwo pogrzebowe Chesed szel Emes pochowało na tym cmentarzu także ciała ofiar akcji wysiedleńczej odnalezione na trasie od synagogi Maharszala po rzeźnię miejską (punkt zborny do deportacji do obozu zagłady w Bełżcu) $)^{32}$. Już po akcji likwidacyjnej (prowadzonej od 16 marca 1942 r.), w kwietniu 1942 r., cmentarz nadal funkcjonował jako miejsce pochówków, o czym świadczą zachowane w aktach Rady Żydowskiej rejestry osób udających się tam z getta szczątkowego na Majdanie Tatarskim na pogrzeby ${ }^{33}$. We wspomnieniach Czesława Górniewicza, więźnia lubelskiego zamku, pojawia się również wzmianka o egzekucjach współwięźniów dokonywanych na cmentarzu żydowskim oraz o pochówkach ofiar zabitych w tym więzieniu. Autor wspomnień sugeruje, że na cmentarzu żydowskim przy ul. Walecznych

25 Tamże, s. 92.

26 Tamże, s. 93. Ul. Franciszkańska biegła w kierunku północnym od dawnego klasztoru Franciszkanów między ul. Unicką a ul. Kalinowszczyzna. Prawdopodobnie jej przedłużeniem była dzisiejsza ul. Walecznych (por. plan Lublina z 1931 r.).

27 Robert Kuwałek, Szlakiem pamięci, [w:] Robert Kuwałek, Wiesław Wysok, Lublin. Jerozolima Królestwa Polskiego, Lublin 2001, s. 122.

28 Józef Tomczyk, Rada Żydowska w Lublinie 1939-1942 - organizacja, działalność i pozostałość aktowa, [w:] Żydzi w Lublinie. Materiały do dziejów społeczności żydowskiej Lublina, t. 1, red. Tadeusz Radzik, Lublin 1995, s. 248.

${ }^{29}$ APL, RŻL, sygn. 6/179, s. 5-7. W dokumentach wymieniono jedną osobę: Mojżesza Sznajdera.

30 Tamże, s. 92.

31 Tadeusz Radzik, Lubelska dzielnica zamknięta, Lublin 1999, s. 45.

${ }^{32}$ Hersz Feldman, Z Majdanu do Dachau, [w:] Księga pamięci żydowskiego Lublina, wstęp, wybór i oprac. Adam Kopciowski, Lublin 2011, s. 331.

33 APL, RŻL, sygn. 6/177, s. 88-92. 
grzebano nie tylko Żydów, ale też innych więźniów (Polaków) ${ }^{34}$. Pochówków dokonywano co najmniej do końca października 1942 r. Można zatem przyjąć, że cmentarz funkcjonował do czasu likwidacji getta szczątkowego na Majdanie Tatarskim, czyli do 9 listopada 1942 r. Liczbę pochówków na tym cmentarzu w latach 1828-1942 szacuje się na 52 tys. ${ }^{35}$ Prawdopodobnie po likwidacji getta na Majdanie Tatarskim cmentarz zniszczono, nagrobki zaś wykorzystano m.in. do brukowania dróg w obozie na Majdanku oraz w obozie na tzw. Flugplatzu przy ul. Wrońskiej ${ }^{36}$. Odwiedzający tę nekropolię ok. roku 1946-1947 Mordechaj Canin pisał, że na terenie cmentarza zastał jedynie pomnik wzniesiony przez ocaleńców ${ }^{37}$ (o którym szerzej w dalszej części artykułu).

\section{Użytkowanie i ochrona cmentarza w latach 1944-1949}

W pierwszych latach po wojnie status mniejszości żydowskiej był stosunkowo lepszy niż pozostałych mniejszości narodowych, które prawo do organizowania się uzyskały dopiero wraz z odwilżą w roku 1956. Było to związane z polityką prowadzoną wobec innych mniejszości uważanych za niebezpieczne z powodu ich własnych dążeń niepodległościowych (jak Ukraińcy) czy przez wzgląd na postrzeganie ich obecności w Polsce jako tymczasowej (np. Niemcy). Sytuację Żydów uważano za wyjątkową z uwagi na doświadczenia wojenne oraz współpracę polskich i żydowskich działaczy lewicowych już w ramach powstałych w ZSRR struktur politycznych ${ }^{38}$. Jak twierdzi August Grabski, istnienie tak rozbudowanych struktur organizacji żydowskich w Polsce jest wyrazem swoistej „,autonomii narodowej”, jaką cieszyła się w tym okresie społeczność żydowska w Polsce ${ }^{39}$. Jednocześnie atmosfera społeczna wobec ludności żydowskiej nie była sprzyjająca. Powtarzające się akty antysemityzmu i przemocy antyżydowskiej wzmagały tendencje emigracyjne i prowadziły do utrzymywania się poczucia zagrożenia. Nie udało się ustalić formalnego statusu własności cmentarza

${ }^{34}$ Czesław Górniewicz, Wspomnienia z okupacji niemieckiej. Pamiętnik więźnia Zamku Lubelskiego, Lublin 2016, s. 104-105, 124.

35 Informacja podana na wystawie autorstwa Roberta Kuwałka w Izbie Pamięci nowego cmentarza żydowskiego w Lublinie.

${ }^{36}$ Kuwałek, Szlakiem pamięci..., s. 122.

${ }^{37}$ Mordechaj Canin, Przez ruiny i zgliszcza. Podróż po stu zgładzonych gminach żydowskich w Polsce, thum. Monika Adamczyk-Garbowska, Warszawa 2018, s. 76.

${ }_{38}$ Bożena Szaynok, Komuniści w Polsce (PPR/PZPR) wobec ludności żydowskiej (19451953), „Pamięć i Sprawiedliwość” (2004), nr 2, s. 186-187.

${ }^{39}$ Grabski, Centralny Komitet Żydów..., s. 39-40. 
w latach czterdziestych XX w. ani sposobu wydzielenia jego części czynnej. Prawdopodobnie, zgodnie z zarządzeniami władz centralnych, przeszedł on jako mienie opuszczone na własność Skarbu Państwa, a następnie został częściowo oddany w użytkowanie powstałej w lutym 1945 r. Żydowskiej Kongregacji Religijnej w Lublinie, o czym będzie mowa w dalszej części artykułu.

W latach powojennych status cmentarza pozostawał niejasny przez dłuższy czas. Było to związane z przedłużającym się nieokreślonym statusem prawnym organizacji żydowskich tuż po wojnie. Po wydaniu ministerialnego okólnika z lutego 1945 r. pozwolono na formalne zawiązanie struktur religijnych. Już 11 lutego 1945 r. powstało w Lublinie Żydowskie Zrzeszenie Religijne ${ }^{40}$. Przemianowano je później - jako organizację ogólnokrajową zrzeszającą lokalne oddziały - na Żydowskie Kongregacje Wyznaniowe, a następnie w 1949 r. utworzono Związek Religijny Wyznania Mojżeszowego (ZRWM). Wszystkie te organizacje religijne posiadały jednak niedookreślony status prawny aż do lat sześćdziesiątych XX w. ${ }^{41}$ W ich kompetencjach miały znajdować się sprawy kultu, dlatego były także uprawnione do występowania o zwrot upaństwowionych obiektów o znaczeniu rytualnym, w tym synagog i cmentarzy. Prawdopodobnie więc opieka nad wydzieloną, czynną częścią nowego cmentarza żydowskiego znalazła się również w ich kompetencjach. Lubelska Kongregacja Wyznaniowa posiadała (czy raczej mogła użytkować) jeden cmentarz - zapewne cmentarz przy ul. Walecznych - zgodnie ze spisem z 1947 r. ${ }^{42}$ Pozostały obszar stał się prawdopodobnie własnością Skarbu Państwa. Należy jednak zaznaczyć, że aktywność lokalnego oddziału żydowskich kongregacji była na Lubelszczyźnie znikoma. Jeszcze w latach 1944-1945 Lublin stanowił ważny ośrodek na mapie odradzającego się w Polsce życia żydowskiego jako pierwsza siedziba Centralnego Komitetu Żydów w Polsce ${ }^{43}$, jednak już wkrótce - w wyniku fal migracji na zachód Polski oraz za granicę - stracił na znaczeniu. Od lat pięćdziesiątych władze lokalne zwracały się jednak $\mathrm{z}$ reguły do lokalnego oddziału Towarzystwa Społeczno-Kulturalnego

${ }^{40}$ Protokół plenarnego posiedzenia Komitetu Żydowskiego w Lublinie z dnia 12 grudnia 1944, Archiwum Żydowskiego Instytutu Historycznego [dalej: AŻIH], Wojewódzki Komitet Żydowski w Lublinie, sygn. 355/4, s. 1-3.

${ }^{41}$ Urban, Cmentarze żydowskie..., s. 193.

${ }^{42}$ Kazimierz Urban, Zagadnienie pożydowskich synagog $i$ cmentarzy $w$ Polsce $w$ latach 1945-1956 (zarys problematyki), „Zeszyty Naukowe Akademii Ekonomicznej w Krakowie” (2005), nr 692, s. 50.

${ }^{43}$ Por. Jacek Jeremicz, Teresa Klimowicz, Organizacja życia żydowskiego po II wojnie światowej, „Scriptores” (2019), nr 46, s. 101-184. 
Żydów w Polsce, traktując właśnie tę organizację jako uprawnioną do reprezentowania mniejszości żydowskiej w rozmaitych sprawach administracyjnych, zwłaszcza że w Lublinie w wielu przypadkach członkowie TSKŻ byli zarazem członkami Kongregacji Religijnej. Obecnie funkcjonujący, czynny cmentarz żydowski utworzono na terenie przedwojennej nekropolii oraz wspominanego cmentarza wojennego i zaczęto użytkować już w roku 1944. Brak jakichkolwiek informacji na temat prowadzonych tam uprzednio ekshumacji. Przypuszczać zatem należy, że pochówków powojennych dokonywano na cmentarzu w miejscach istniejących już grobów z okresu przedwojennego.

Jak donosił „Biuletyn Żydowskiej Agencji Prasowej”, pierwszy powojenny pochówek odbył się już 23 listopada $1944 \mathrm{r}$. Informacja dotyczyła pogrzebu dra Zygfryda Wienera, docenta Uniwersytetu Marii Curie-Skłodowskiej w Lublinie (UMCS), który zginął w wypadku komunikacyjnym. Nota podkreślała, że był to pierwszy pogrzeb żydowski w wyzwolonym Lublinie, na który przybyli przedstawiciele rządu, rabin dr R. Safrin Feldszuh oraz rektor UMCS prof. Henryk Raabe ${ }^{44}$. Jednak zgodnie z relacją Ewy Eisenkeit pierwszym pochówkiem w 1944 r. był pogrzeb żydowskiego żołnierza Wojska Polskiego, którego znaleziono martwego w piwnicy przy ul. Świętoduskiej. W pogrzebie miała uczestniczyć duża grupa ocalonych Żydów z różnych rejonów Polski, a ceremonię prowadził rabin ${ }^{45}$ zamieszkały wówczas przy ul. Lubartowskiej 18 . W $1945 \mathrm{r}$. na cmentarzu pochowano także trzech żołnierzy, którzy zmarli w Szpitalu Okręgowym nr 2 w Lublinie, często w wyniku odniesionych na froncie $\operatorname{ran}^{46}$. Dokładna lokalizacja tych pochówków nie jest obecnie możliwa. Być może zostały one objęte planem łączenia kwater w ramach inwestycji polegającej na uporządkowaniu cmentarza i połączeniu kwater, którą w 1964 r. przeprowadził Wydział Gospodarki Komunalnej Miejskiej Rady Narodowej w Lublinie (o czym dalej).

Niestety nie zachowała się księga żydowskiego cmentarza za lata 19441962. Przetrwały jednak adnotacje będące prawdopodobnie planowanymi inskrypcjami nagrobnymi dla pochowanych. Można z nich wywnioskować, że w 1946 r. dokonano na cmentarzu pochówku przynajmniej sześciu

${ }^{44}$ „Biuletyn Żydowskiej Agencji Prasowej” (23 listopada 1944), AŻIH, „Biuletyn Żydowskiej Agencji Prasowej” 1944-1949, sygn. 354, k. 2.

${ }_{5}^{45}$ Esther Minars, A Lublin Survivor: Life Is Like a Dream. As Told by Eva Eisenkeit, Brighton 2019, s. 337.

${ }_{46}$ Archiwum Archidiecezji Częstochowskiej, Zgony za lata 1944-1945, poz. 126, 158, 163, 175, https://FamilySearch.org [dostęp: 6 stycznia 2020]. 
osób, w tym Chaima Hirszmana, ocalonego z obozu w Bełżcu i zamordowanego w 1946 r. w Lublinie ${ }^{47}$. Należy przypuszczać, że pochowano tam także Leona Felhendlera, jednego z przywódców buntu w obozie w Sobiborze, zabitego w Lublinie w 1945 r., a może również siedem pozostałych ofiar powojennych zajść antysemickich w Lublinie ${ }^{48}$. Sprawa ta jest jednak trudna do ustalenia, gdyż w aktach stanu cywilnego nie umieszcza się informacji o miejscu pochówku zmarłych. W tym okresie porządek polityczny w Polsce dopiero się kształtował w swojej ostatecznej formie. CKŻP stanowił forum ścierania się rozmaitych poglądów politycznych od frakcji syjonistycznych, przez odradzający się Bund, po komunistów z tzw. Frakcji Żydowskiej PPR. Polem konfliktu na łamach CKŻP były sprawy wyznaniowe, jak również kwestie tożsamościowe związane ze skalą oczekiwanej asymilacji oraz politycznego zaangażowania (kultura jidysz miała być „narodowa w formie i socjalistyczna w treści”).

15 grudnia 1946 r. w „Gazecie Lubelskiej” pojawiła się informacja o odbywającym się w tym dniu pogrzebie Żydów ekshumowanych na terenie Majdanu Tatarskiego. Kondukt pogrzebowy miał wyruszyć z domu przy ul. Lubartowskiej 8 (obecnie Lubartowska 10) na cmentarz żydowski przy ul. Unickiej. Komitet Pogrzebowy wzywał wszystkich Żydów oraz całe społeczeństwo do wzięcia jak najliczniejszego udziału w uroczystości ${ }^{49}$. O pogrzebie donosił także „Sztandar Ludu”:

W niedzielę bm. odbył się ich pogrzeb. Zwłoki przewieziono z Majdanu Tatarskiego w 9 czarnych skrzyniach na ul. Lubartowską, przed dom, w którym mieści się Kongregacja Żydów Lubelskich ${ }^{50}$, skąd wyruszył kondukt na cmentarz żydowski. Pochód otwierała grupa dzieci z wieńcami, potem szła delegacja Wojewódzkiego Komitetu Żydów Polskich z wieńcem i sztandarem biało-niebieskim, 2 skromne platformy ze szczątkami męczenników, za którymi w głębokim smutku kroczyli niedobitki społeczeństwa żydowskiego. Ci, którym udało się ujść z życiem z rąk siepaczy niemieckich, odprowadzali na miejsce wiecznego odpoczynku ofiary barbarzyństwa. Nie tylko Żydzi brali udział w pogrzebie. Społeczeństwo polskie było licznie reprezentowane. Nad otwartą mogiłą przemówili przedstawiciele PPS i PPR. Wspomnieli o zbrodniach niemieckich okresu okupacji. Podkreślili, że gdyby nie

${ }^{47}$ Notatka Szulima Garena, Archiwum Romana Litmana. Autorka pragnie podziękować p. Romanowi Litmanowi oraz dr. hab. Adamowi Kopciowskiemu za udostępnienie tych materiałów. Nie udało się zlokalizować dokładnego miejsca pochówku Chaima Hirszmana w obecnej przestrzeni cmentarza.

${ }^{48}$ Por. Adam Kopciowski, Zajścia antyżydowskie na Lubelszczyźnie w pierwszych latach po II wojnie światowej, „Scriptores” (2019), nr 46, s. 229.

${ }^{49}$ Pogrzeb Żydów ofiar zbrodni hitlerowskich, „Gazeta Lubelska” (15 grudnia 1946), s. 6.

${ }^{50}$ Ul. Lubartowska 10, synagoga Bractwa Pogrzebowego „Chewra Nosim”. 
interwencja Armii Polskiej i Czerwonej, los narodu polskiego byłby nie mniej tragiczny od losu Żydów. W nowej Polsce nie ma miejsca na uprzedzenia rasowe. Wszyscy staną razem, jak równi z równymi, by we wspólnym wysiłku odbudować to, co niemieccy barbarzyńcy zniszczyli. Następnie przemawiali przedstawiciele Wojewódzkiego Komitetu Żydów Polskich, Kongregacji Żydów Lubelskich oraz społeczeństwa żydowskiego. Kiedy w słowach prostych i niewyszukanych mówili o męczeństwie Żydów, bolesny szloch wydarł się z piersi obecnych ${ }^{51}$.

Podczas ceremonii wykonywano także zdjęcia, które przesłano na początku 1947 r. do Centralnej Żydowskiej Komisji Historycznej w Łodzi ${ }^{52}$. Przestrzeń cmentarza, jak również sama społeczność żydowska, stanowiła zatem pole walki ideologicznej, politycznej (,gdyby nie interwencja Armii Polskiej i Czerwonej, los narodu polskiego byłby nie mniej tragiczny od losu Żydów”) i pretekst do kształtowania właściwych postaw społecznych („W nowej Polsce nie ma miejsca na uprzedzenia rasowe”).

Z drugiej strony, środowiska żydowskie również wykazywały zainteresowanie w tworzeniu własnej polityki historycznej. We wczesnych latach powojennych widoczna jest aktywność lokalnej społeczności żydowskiej, a także organizacji zrzeszających lubelskich Żydów, tzw. ziomkostw. Ziomkostwa powstawały jeszcze w okresie przedwojennym, zrzeszając emigrantów żydowskich z Polski, którzy dążyli do utrzymania związków z Żydami pozostającymi w rodzinnych miejscowościach. Po wojnie, ponieważ większość przedwojennych skupisk żydowskich przestała istnieć, aktywność ziomkostw koncentrowała się na udzielaniu wsparcia materialnego oraz na zabezpieczaniu dziedzictwa żydowskiego w Polsce. Na rosnące zaangażowanie ziomkostw należy spojrzeć także w kontekście wydarzeń pogromu kieleckiego w lipcu $1946 \mathrm{r}$. oraz antysemickiej przemocy w tym czasie w samym regionie lubelskim ${ }^{53}$. Wydarzenia te były wykorzystywane przez władze lokalne i państwowe do walki z przeciwnikami politycznymi, ale też stanowiły propagandowe wyrazy wsparcia dla lokalnej społeczności żydowskiej. Prawdopodobnie wpłynęły też na zmianę polityki emigracyjnej państwa na początku 1947 r. Zagraniczne wsparcie miało więc duże znaczenie moralne, jak również odpowiadało na konkretne potrzeby materialne.

${ }^{51}$ Pogrzeb Żydów pomordowanych w 1942 roku na Majdanie Tatarskim, „Sztandar Ludu" (17 grudnia 1946).

52 AŻIH, Centralna Żydowska Komisja Historyczna, 303/20, sygn. 114, s. 89.

${ }_{53}$ Por. Kopciowski, Zajścia antyżydowskie..., s. 222. 


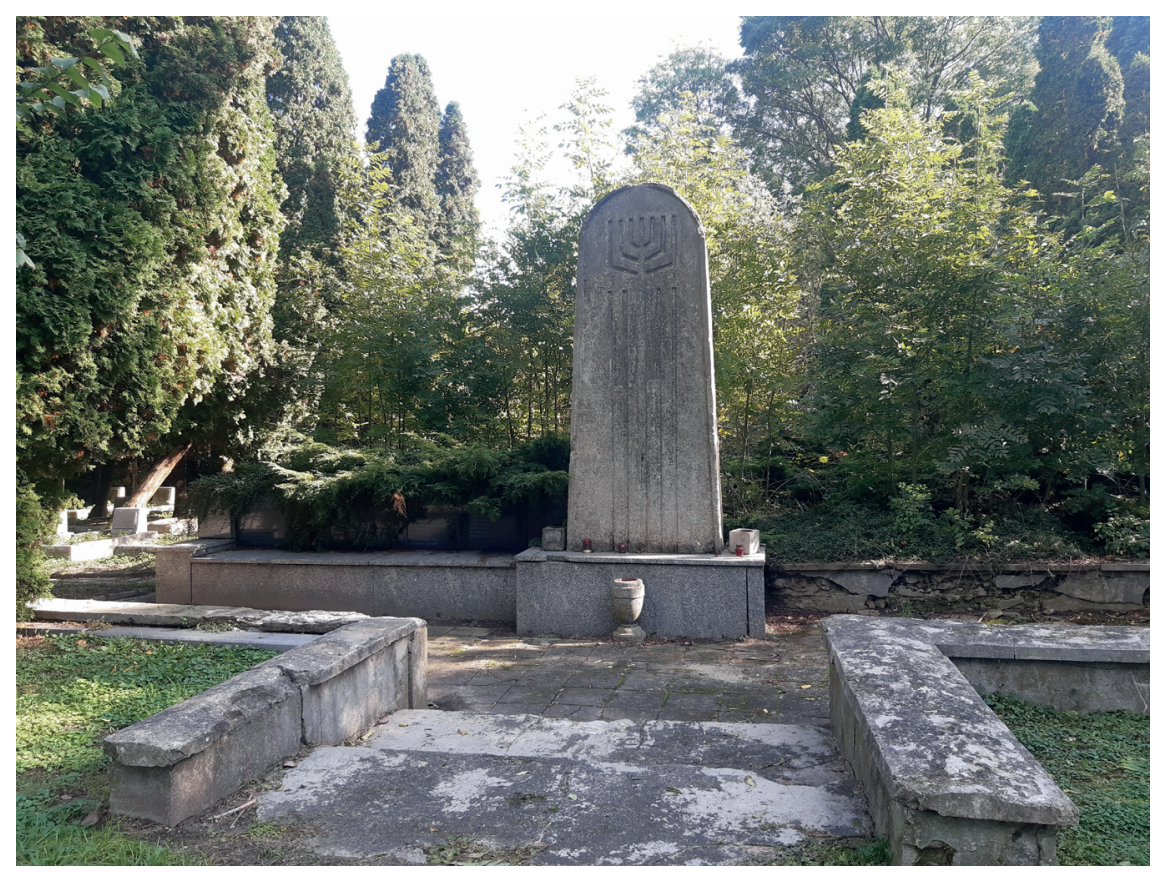

Il. 2. Pomnik Pomordowanych Żydów Lublina; fot. Teresa Klimowicz, 2020.

Poczucie zagrożenia - nieustające pomimo zakończenia wojny - wpływało też na konsolidację społeczności żydowskiej. W trakcie odbywającego się we wrześniu 1947 r. Zjazdu Lublinerów ${ }^{54}$ dokonano pogrzebu 40 ekshumowanych ofiar egzekucji w Jakubowicach Murowanych oraz odsłonięto pomnik Ofiar Getta na Majdanie Tatarskim ${ }^{55}$. Chodzi tu zapewne o istniejaccy pomnik Pomordowanych Żydów Lublina (il. 2), który upamiętnia jednocześnie żydowskich jeńców z obozu przy ul. Lipowej oraz żydowskich żołnierzy Wojska Polskiego poległych w latach 1939-194456. Monument ten, nieznanego autorstwa, ma kształt macewy z reliefem w kształcie menory i otoczony jest niskim murkiem z granitu, w który w 1996 r. wmurowano tablice z listami nazwisk oraz napis dedykacyjny o treści: „Ku pamięci ludności żydowskiej / miasta Lublina wymordowanej przez / hitlerowców w latach 1939-1944 / Cześć ich pamięci”. Pierwotnie dedykacja była nieco inna: w miejscu „hitlerowców” znajdowało się

\footnotetext{
54 Jeremicz, Klimowicz, Organizacja..., s. 122.

55 Por.: Księga pamięci..., s. 52.

56 Kazimierz S. Ożóg, Pomniki Lublina, Lublin 2014, s. 102.
} 
sformułowanie „zbirów hitlerowskich”. Poniżej znajduje się też napis: „Tu spoczywają Żydzi / żołnierze Wojska Polskiego / polegli w walce z hitlerowcami / w latach 1939-1944 / i jeńcy zamordowani w obozie jenieckim / przy ul. Lipowej w Lublinie / Cześć ich pamięci" ${ }^{57}$.

Także w późniejszym okresie Ziomkostwo Żydów Lubelskich podejmowało działania zmierzające do zachowania obu (starego przy ul. Siennej oraz nowego przy ul. Unickiej) lubelskich cmentarzy. W planach znalazło się ogrodzenie nowego cmentarza, na co zamierzano pozyskać środki z dotacji CKŻP oraz Jointu ${ }^{58}$. W wyniku starań Ziomkostwa i osobistego zaangażowania Arona Nissenbauma (przed wojną działacza lubelskiego Bundu i redaktora jego organu prasowego „Lubliner Sztyme”) prace ogrodzeniowe na odcinku $1100 \mathrm{~m}$ zostały sfinalizowane ${ }^{59} \mathrm{~W}$ połowie maja 1948 r., po czym przystąiono do plantowania terenu. W tym samym czasie przeprowadzono także - na koszt Symchy Ajchenbauma (aktywnego działacza lubelskiego Ziomkostwa, mieszkającego w tym czasie w Szczecinie) remont ohelu Majera Szapiry ${ }^{60}$. Rozpoczęto również proces zwożenia na teren nowego cmentarza nagrobków odnajdywanych na terenie miasta oraz zatrudniono dozorców odpowiedzialnych za porządek na starej i nowej nekropolii ${ }^{61}$. W marcu 1948 r. przeprowadzono ekshumację dzieci z żydowskiej ochronki przy ul. Grodzkiej, które zginęły w masowej egzekucji 24 marca 1942 r. na Majdanie Tatarskim, i odprawiono uroczysty pogrzeb ofiar w zbiorowej mogile ${ }^{62}$. W miejscu ich pochówku postawiono w $1987 \mathrm{r}$. pomnik autorstwa Sławomira Mieleszki w kształcie menory (będzie szerzej omówiony w dalszej części tekstu) ${ }^{63}$. Aktywność społeczności żydowskiej na terenie cmentarza w tym czasie wskazuje na próbę zachowania obecności i utrzymania pewnej niezależności tożsamościowej i politycznej wyrażanej m.in. zainteresowaniem wielowiekowym dziedzictwem żydowskim w Lublinie i wolą wzięcia za nie odpowiedzialności. Lata czterdzieste XX w. - czas względnej autonomii organizacji żydowskich - pozwalały

57 Tamże, s. 102.

${ }^{58}$ Więcej o działalności Joint w powojennej Polsce zob.: Anna Sommer Schneider, Sze'erit hapleta. Ocaleni z Zagłady. Działalność American Jewish Joint Distribution Committee w Polsce w latach 1945-1989, Kraków 2014.

${ }^{59}$ Icchok Rajchensztajn, Ziomkostwo lubelskie w Polsce, [w:] Księga pamięci..., s. 360.

${ }^{60}$ Izba Pamięci Żydów Lublina, Zeszyt protokołów posiedzeń Prezydium Ziomkostwa Lubelskiego z 2 stycznia 1948 - 13 listopada 1949, s. 1, 10, 28, 40, 52, za: Księga pamięci..., s. 55.

${ }^{61}$ Tamże, s. 56.

${ }^{62}$ Tamże.

${ }^{63}$ Ożóg, Pomniki Lublina..., s. 140. 
na użytkowanie znacznie już zniszczonej nekropolii i zachowanie pamięci o niej. Pojawianie się w lokalnej prasie informacji o uroczystych pochówkach na terenie cmentarza świadczy także o pierwszych próbach upolitycznienia pamięci o żydowskich ofiarach przez władze lokalne i wpisanie jej w ogólnokrajowe ceremonie o podobnym charakterze (il. 3).

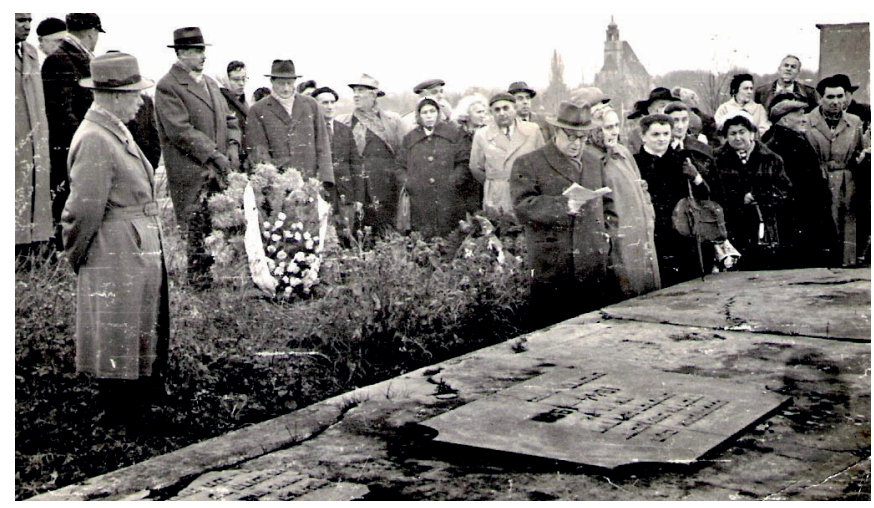

Il. 3. Ceremonia złożenia hołdu zamordowanym Żydom Lublina, nowy cmentarz żydowski przy ul. Walecznych, ze zbiorów Ośrodka „Brama Grodzka - Teatr NN”, Lublin 1955-1958, kolekcja ikonograficzna Józefa Kligera.

\section{Cmentarz w epoce likwidacji autonomii żydowskiej}

Od 1950 r. sytuacja społeczności żydowskiej w Polsce zaczęła się zmieniać. Kształtująca się w drugiej połowie lat czterdziestych autonomia ulegała stopniowemu ograniczaniu ${ }^{64}$. Zmienił się także stosunek rządu polskiego do państwa Izrael, a zarazem polityka wobec działających w kraju organizacji syjonistycznych. Władze uważały bowiem nielegalnych żydowskich emigrantów za „dezerterów z frontu budowy socjalistycznej ojczyzny”, podżeganych przez syjonistów i osłabiających sukces rewolucji socjalistycznej. Zlikwidowano Centralny Komitet Żydów Polskich, a w jego miejsce powołano Towarzystwo Społeczno-Kulturalne Żydów w Polsce. Żydowskie Kongregacje Wyznaniowe formalnie nadal funkcjonowały, jednak - przede wszystkim w Lublinie - Kongregacja miała marginalne znaczenie. W skali kraju liczba Kongregacji zmniejszała się, a Związek Religijny Wyznania

${ }^{64}$ Zob. Grzegorz Berendt, Życie od nowa. Instytucje i organizacje żydowskie (19441950), [w:] Następstwa zagłady Żydów. Polska 1944-2010, red. Monika Adamczyk-Garbowska, Feliks Tych, Lublin 2011, s. 211-214. 
Mojżeszowego (ZRWM) deklarował lojalność wobec władz państwowych. Pojawił się także problem niejasnego podziału kompetencji organizacji żydowskich. Choć formalnie cmentarze powinny znajdować się pod opieką Kongregacji, to w praktyce sprawy kultu, w tym zarządzania cmentarzami żydowskimi, konsultowano z TSKŻ. Stan cmentarzy żydowskich pozostawiał wiele do życzenia. Na ich ruinę i dewastację uwagę zwracały różne podmioty zarówno krajowe, jak i zagraniczne - od Milicji Obywatelskiej po Ziomkostwo. Problem odpowiedzialności za ich utrzymanie i zarządzanie był związany z jednoczesnym funkcjonowaniem ZRWM, któremu formalnie podlegać powinny cmentarze, oraz właśnie TSKŻ. Prawdopodobnie jednak, jak już wspomniano, w lubelskich realiach te same osoby wchodziły w skład TSKŻ i Związku Religijnego (liczącego wówczas 40 osób $\left.^{65}\right)$. O zatargach na tym tle świadczyć może sprawa zarzutów formułowanych pod adresem przedstawiciela Związku Religijnego w Lublinie, Dorfsmana, który przez pewien czas był również członkiem TSKŻ. Sprawa dotyczyła zarządzania i opieki nad nowym cmentarzem żydowskim, na którym zniszczeniu miały ulec nagrobki z lat czterdziestych XX w. oraz pomnik na masowej mogile pomordowanych Żydów ${ }^{66}$.

Informacje $z$ lat pięćdziesiątych dotyczące omawianego cmentarza są szczątkowe i niepewne. Brak materiałów archiwalnych oraz obecności cmentarza w prasie należy jednak również traktować jako znaczące. W tym czasie następuje wzrost kontroli, inwigilacji i ataków na środowiska żydowskie, ograniczona zostaje działalność komitetów żydowskich i organizacji zagranicznych, nie ma także finansowego wsparcia z American Jewish Joint Distribution Committee, którego działalność na terenie Polski zawieszono $^{67}$. Był to czas zamierania żydowskiego życia religijnego, a kampania antysemicka, której kulminacją były wydarzenia marcowe, zaczynała się już kształtować pod hasłem walki z „żydowskim nacjonalizmem”. Społeczność żydowska Lublina skupiła się przede wszystkim wokół laicko nastawionego TSKŻ, działalność zaś Żydowskiej Kongregacji Wyznaniowej została zawieszona w 1954 r. ${ }^{68} \mathrm{O}$ nastawieniu lubelskiego TSKŻ świadczyć może też sprawa budowy pomnika partyzantów żydowskich pochowanych na

${ }^{65}$ Archiwum Akt Nowych [dalej: AAN], Urząd ds. Wyznań [dalej: UdsW], sygn. 13/433, za: Urban, Cmentarze żydowskie..., s. 358.

${ }^{66}$ AŻIH, Towarzystwo Społeczno-Kulturalne Żydów w Polsce [dalej: TSKŻ], dokument z 18 grudnia 1953 r., sygn. 325/217, b.p.

${ }^{67}$ Sommer Schneider, Sze'erit hapleta..., s. 155-167, 171-172.

${ }_{68}$ Teresa Klimowicz, Lubelski Oddziat Towarzystwa Społeczno-Kulturalnego Żydów w Polsce w latach 1950-1968, „Scriptores” (2019), nr 46, s. 368. 
cmentarzu wojskowym przy ul. Białej. Lubelski oddział TSKŻ zwracał się o „wykorzystanie płyt z cmentarzy zdewastowanych" z przeznaczeniem na ten cel ${ }^{69}$. W 1952 r. Wydział ds. Wyznań Urzędu Wojewódzkiego w Lublinie na podlegającym mu obszarze prowadził spis nieruchomości żydowskich, w którym powierzchnię cmentarza określono na 8,5 ha, a stopień zniszczenia na 50 procent $^{70}$, co mogłoby sugerować, że w tym czasie na terenie nekropolii istniały jeszcze jakieś nagrobki (być może pochodzące z drugiej połowy lat czterdziestych XX w.). Atmosfera lat pięćdziesiątych XX w. była coraz bardziej niekorzystna dla zachowania nekropolii żydowskich. Pomimo zapisów prawnych pozwalających na likwidację cmentarza dopiero po pięćdziesięciu latach od ostatniego pochówku cmentarze żydowskie przeznaczano na inne cele już od lat pięćdziesiątych ${ }^{71}$. Prawdopodobnie to właśnie z możliwością ponownego wykorzystania własności przedwojennych żydowskich gmin wyznaniowych związane były podjęte działania inwentaryzacyjne.

Przemiany 1956 r. odbijały się silnym echem także na społeczności żydowskiej. Zgodnie z przyjętą linią władz państwowych zaczęto w niektórych kręgach obarczać Żydów winą za błędy i wypaczenia z okresu stalinizmu. Także w samym TSKŻ podejmowano próby rozliczeń, a na III Krajowym Zjeździe tego Towarzystwa w 1956 r. skrytykowano dotychczasową politykę ideologiczno-programową, zarzucając jej m.in. lekceważenie religijnych Żydów. Przez Polskę przetoczyła się wówczas również fala antysemickich incydentów. Jednocześnie otwarta została droga emigracji (z czego wielu korzystało) oraz nastąpiła poprawa stosunków z Izraelem.

W 1958 r. brat rabina Majera Szapiry, korzystając z tej sytuacji (zapewne z obawy o profanację), przewiózł zwłoki tego wielkiego talmudysty i twórcy uczelni rabinackiej z Lublina do Jerozolimy, gdzie pochowano je na cmentarzu Har ha-Menuchot. W Lublinie pozostał do dzisiaj jego symboliczny, pusty już ohel (il. 4) ${ }^{72}$. W ekshumacji zwłok uczestniczył lubelski parasolnik Nuchym Szyc ${ }^{73}$, który w następujący sposób pisał o przeżyciach związanych $\mathrm{z}$ tym wydarzeniem:

${ }^{69}$ AŻIH, TSKŻ, sygn. 325/217, b.p.

70 APL, Urząd Wojewódzki Lubelski (Zespół 1079) [dalej: UWL], Wydział ds. Wyznań [dalej: WdsW], sygn. 353, s. 48.

${ }_{71}$ August Grabski, Albert Stankowski, Życie religijne społeczności żydowskiej, [w:] Nastęstwa zagłady Żydów..., s. 220.

${ }^{72}$ Karolina Wajs, Symcha Wajs, Fakty $i$ wydarzenia z życia lubelskich Żydów, Lublin 1997, s. 54.

${ }_{73}$ Notatka z rozmowy autorki z p. Romanem Litmanem, 12 lipca 2019. 


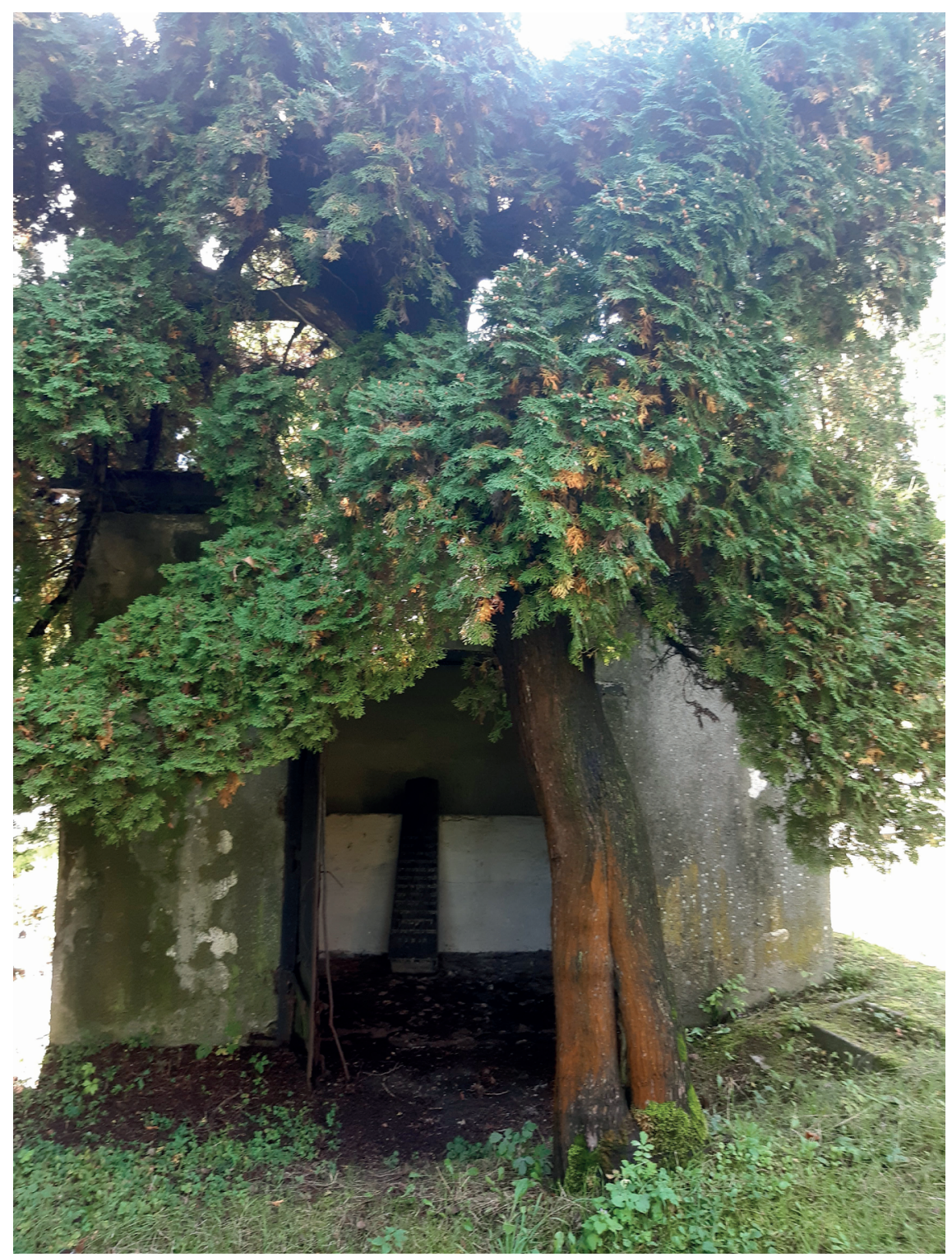

Il. 4. Pusty ohel nad dawnym grobem Majera Szapiry; fot. Teresa Klimowicz, 2020.

W roku 1958 miałem zaszczyt ekshumować zwłoki Rabina Szapiro. [...] Przysłany do pracy człowiek, który był w danej chwili jedynym Żydem - zrobił na mnie przykre wrażenie. Jego donośny głos i pewność siebie miały w sobie coś odpychającego, ale jego fizyczna budowa świadczyła o tym, że nadawał się do danej pracy, lecz kiedy zwrócił mi kilkakrotnie krytyczne uwagi na temat spraw jego niedoty- 
czących - chciałem stanowczo zrezygnować z jego pomocy. Lecz on energicznym ruchem sięgnął po łopatę i rzekł: „Szkoda czasu, trzeba zaczynać kopać”. Jego wesoła twarz tryskająca zdrowiem nie odpowiadała tej powadze chwili, która się odbywała. [...] Ten człowiek stał mi się jakby bliższym. Zdawało mi się, że z taką energią i powagą mogli tylko pracować Haluce na bagnach. Jego głos stał się bardziej cichy i pot coraz więcej rosił jego czoło. Zaproponowałem odpoczynek w pracy, lecz on tylko kiwnął mi przecząco głową i kopał dalej; gdy dokopał się do desek przykrywających zwłoki zmarłego, twarz jego stała się blada i z piersi jego wyrwał się przytłumiony głos. „Wybacz mistrzu, to dla Twego honoru” [...] Moje łzy zmieszały się z jego płaczem, przyklęknął, oparł się głową o ścianę grobu, rękoma zaczął odgarniać ziemię, która przylegała do prochów zmarłego. Czynił to tak, jakby wyjmował drogie relikwie - powoli i ostrożnie. [...] Gdy wyszedł po skończonej pracy z dołu, twarz jego była w dalszym ciągu blada, ręce lekko drżały i pierś unosiła się poruszana płaczem. Stanął z boku cichy, skromny, jakby przybity bólem, a modlitwy nikt nie odmawiał ${ }^{74}$.

Świadectwo to obrazuje atmosferę tych czasów: poczucie osamotnienia i opuszczenia, zdziesiątkowanie miejscowej społeczności żydowskiej (,jedyny Żyd”), a zarazem nostalgię za dawną świetnością reprezentowaną przez sakralizowane zwłoki uczonego oraz potrzebę poczucia wspólnotowości utraconą w pragmatyzmie przetrwania i sekularyzacji (,,a modlitwy nikt nie odmawiał").

W Lublinie podejmowano także działania upamiętniające. W $1958 \mathrm{r}$. odnowiono ohel (namiot, rodzaj zadaszenia umieszczanego nad grobami, a w tym przypadku niewielki budynek) rodziny Eigerów, stanowiącej dynastię przywódców chasydzkich ${ }^{75}$. W dokumentach z lat osiemdziesiątych XX w. pojawia się również wzmianka o ekshumacji, także w 1958 r., dwu tysięcy żydowskich ofiar egzekucji z czasów II wojny światowej z terenu Lubelszczyzny i pochowaniu tych szczątków właśnie na cmentarzu żydowskim w Lublinie ${ }^{76}$. Informacja ta jednak podawana jest jedynie za odpisami inwentaryzacyjnymi z 1966 r. Fragmentaryczność dokumentacji oraz innych świadectw z tego okresu pozwala jedynie na stawianie hipotez dotyczących polityki wobec omawianego cmentarza. Aktywność organizacji zagranicznych oraz członków rodziny pozwoliły najwyraźniej na przeniesienie

${ }^{74}$ Nuchym Szyc, Płacz zamiast modlitwy, 1988, oprac. Łukasz Jasina, 2006, OBGTNN, http://biblioteka.teatrnn.pl/dlibra/Content/9626/Placz_zamiast_modlitwy.pdf [dostęp: 5 listopada 2019].

${ }^{75}$ Kuwałek, Szlakiem pamięci..., s. 122. Jak podaje Marcin Wodziński, Fundacja Sary i Manfreda Frenklów w 1999 r. umieściła na zrujnowanym ohelu tablicę pamiątkową z nazwiskami. Por.: Marcin Wodziński, Groby cadyków w Polsce. O chasydzkiej literaturze nagrobnej i jej kontekstach, Wrocław 1998, s. 206-207.

${ }_{76}$ APL, UWL, UdsW, sygn. 354, s. 12. 
zwłok Majera Szapiry. Trzeba podkreślić, że wszelkie kontakty środowisk żydowskich $\mathrm{z}$ organizacjami zagranicznymi były monitorowane i postrzegane jako element polityki zagranicznej państwa, jednak jednocześnie gest ten świadczy o braku świadomości władz lokalnych o znaczeniu tej postaci i istotności jego miejsca pochówku. Sądzono wprawdzie, że cmentarz żydowski może być przestrzenią ewentualnych manifestacji politycznych, ale nie podejmowano działań zmierzających do zachowania przedwojennego dziedzictwa żydowskiego Lublina, traktowanego najwyraźniej jako element co najwyżej obojętny (jeśli nie obcy) dla historii miasta.

Warto zaznaczyć, że koniec lat pięćdziesiątych XX w. przyniósł pewną poprawę sytuacji. Wznowiono pomoc płynącą poprzez Joint z zagranicy, dążąc jednocześnie do wzmocnienia pozycji TSKŻ jako organizacji, która mogłaby pośredniczyć w uzyskaniu wsparcia. Ostatecznie jednak powstała w 1957 r. Centralna Żydowska Komisja Pomocy Społecznej, dysponująca środkami z Jointu pod kontrolą Urzędu ds. Wyznań oraz łącząca przy tym środowiska TSKŻ i ZRWM ${ }^{77}$. Środki te przeznaczano przede wszystkim na bieżące potrzeby życiowe członków, a jedynie w niewielkiej części na utrzymanie nekropolii żydowskich w Polsce.

\section{Ochrona cmentarza w latach sześćdziesiątych}

Zmiany polityczne na początku lat sześćdziesiątych XX w. nie wpływały korzystnie na sytuację społeczności żydowskiej. Ponownie wzmożono kontrolę i inwigilację środowiska TSKŻ, obniżono dotację państwową, oskarżano Joint o działalność agenturalną. Narastał także konflikt między TSKŻ a ZRWM związany z dystrybucją płynącego z zagranicy wsparcia finansowego. TSKŻ niechętnie wspomagał miejsca kultu, w tym opiekę nad żydowskimi nekropoliami. Z drugiej strony, w roku 1961 podjęto wreszcie dalsze kroki zmierzające do uznania statutu ZRWM i wyjaśnienia jego statusu prawnego, umieszczając opiekę nad cmentarzami (w myśl wcześniejszych postanowień) w jego kompetencjach.

Początek lat sześćdziesiątych XX w. to także nowy rozdział w polityce zarządzania cmentarzami żydowskimi. W 1959 r. pojawiła się nowa Ustawa o cmentarzach i chowaniu zmarłych ${ }^{78}$, pozwalająca na przeznaczenie nekropolii na inny cel po czterdziestu latach od ostatniego

77 Sommer Schneider, Sze'erit hapleta..., s. 220.

${ }^{78}$ Ustawa z dnia 31 stycznia 1959 r. o cmentarzach i chowaniu zmarłych, Dz.U. 1959, nr 11, poz. 62. 
pochówku, a nawet - w uzasadnionych interesem użyteczności publicznej przypadkach - po okresie krótszym. Obowiązek utrzymywania cmentarzy będących w gestii organów gospodarki komunalnej (wyrażony też w Okólniku nr 11 Ministra Gospodarki Komunalnej z 3 sierpnia 1964 r. w sprawie cmentarzy nieczynnych ${ }^{79}$ ) sprawiał, że poszczególne władze lokalne dążyły do jak najszybszego zamknięcia nekropolii różnych wyznań, a tym samym uwolnienia się od problemu i odpowiedzialności (także finansowej). W następnych latach polityka zamykania cmentarzy zmierzała do uproszczenia tej procedury. Praktyka ta wpisywała się w szerszy proces laicyzacji społeczeństwa, a nawet była - jak zauważają badacze ${ }^{80}$ - wymierzona przeciwko Kościołowi katolickiemu, uderzając jednocześnie w inne wyznania. W połowie lat sześćdziesiątych XX w. o żydowskie nekropolie upominał się w obszernym memoriale Wawa Morejno z Łodzi, a także przedstawiciele środowisk żydowskich w $\mathrm{USA}^{81}$. W Lublinie w tym okresie mimo wszystko nadal funkcjonowała Żydowska Kongregacja Wyznaniowa, która była właścicielem (czy raczej dysponentem) czynnej części cmentarza, a także świadczyła ostatnią posługę członkom miejscowej społeczności ${ }^{82}$. W 1960 r. na terenie lubelskiego cmentarza wybuchł pożar wzniecony najprawdopodobniej przez przekradające się przez parkan dzieci. Pożar został ugaszony dzięki interwencji straży pożarnej ${ }^{83}$. Widać zatem, że przestrzeń ta nie była traktowana z należytym szacunkiem, lecz zaniedbana i pozostająca poza kontrolą, co pozwalało na takie dewastacje i profanacje.

Sytuację cmentarzy żydowskich w Polsce miał odmienić pogrzeb Michała Szuldenfreia na cmentarzu żydowskim przy ul. Okopowej w Warszawie latem 1965 r. Uczestniczący w uroczystości ówczesny premier Józef Cyrankiewicz miał być zbulwersowany stanem nekropolii i zażądać wyjaśnień od TSKŻ. Na fali tej krytyki pojawiły się także głosy o konieczności uporządkowania lubelskich nekropolii żydowskich, opisane przez Jewish Telegraphic Agency $^{84}$. W latach 1964-1965 w ramach roztaczanej przez Kongregację Wyznaniową opieki jako dozorca cmentarza zatrudniony został Stanisław Trześniewski ${ }^{85}$. Cmentarz ponadto był źródłem niewielkiego przychodu

79 Dziennik Urzędowy Ministerstwa Gospodarki Komunalnej nr 11 z 1964 r., poz. 56, za: Urban, Cmentarze żydowskie..., s. 649-652.

${ }^{80}$ Bielawski, Zagłada cmentarzy żydowskich..., s. 73.

${ }^{81}$ Urban, Cmentarze żydowskie..., s. 665-712.

82 APL, UWL, UdsW, sygn. 353, s. 114.

83 Dzieci wzniecily pożar, „Kurier Lubelski” (16 marca 1960), s. 3.

${ }^{84}$ Sommer Schneider, Sze'erit hapleta..., s. 278.

85 Tamże, s. 121. 
dla Kongregacji dzięki sprzedaży siana pochodzącego z terenu nekropolii ${ }^{86}$. Choć w tym czasie aktywność lubelskiej społeczności zwróciła się w stronę cmentarzy, a w TSKŻ powołano specjalny komitet ${ }^{87}$ zajmujący się tymi sprawami, to jego działalność skupiała się przede wszystkim na zachowaniu starego cmentarza żydowskiego przy ul. Siennej ${ }^{88}$. Pewne czynności w zakresie inwentaryzacji i zachowania nekropolii prowadziły też władze państwowe (będące de iure właścicielami wszystkich cmentarzy żydowskich) zmuszone wspominanym okólnikiem z 1964 r. do uporządkowania spraw cmentarnych.

W 1965 r. - prawdopodobnie jednocześnie z akcją grodzenia i porządkowania nieczynnych cmentarzy prowadzoną w województwie lubelskim od 1964 r. przez Wojewódzkie Zrzeszenie Gospodarki Komunalnej ${ }^{89}$ przystąpiono do czynności porządkowych na omawianym cmentarzu. Inwestorem prac był Wydział Gospodarki Komunalnej i Mieszkaniowej przy Prezydium Miejskiej Rady Narodowej (MRN). Miejscowa Kongregacja wyceniała koszt naprawy na 460 tys. zł. Na renowację 150 tys. zł przekazał także komitet budowy pomnika ku czci Masowej Eksterminacji Ludności Żydowskiej (odsłoniętego w 1963 r.), 260 tys. zł pozyskano z Centralnej Żydowskiej Komisji Pomocy Społecznej. Według lubelskiej KongregacjiMRN miała przeznaczyć na ten cel 50 tys. $\mathrm{z}^{190}$. W Wojewódzkim Biurze Projektów przygotowano projekt zagospodarowania terenu, zadanie do realizacji zaś zlecono we wrześniu $1966 \mathrm{r}$. Na potrzeby przygotowania prac sporządzono także inwentaryzację istniejących grobów ${ }^{91}$, których na planie wskazano 68. Ogrodzono wówczas również część użytkową cmentarza, co zachowało się do dzisiejszego dnia ${ }^{92}$. Planowano także ustawienie sporego znicza z blachy miedzianej. Teren zamierzano obsadzić kwiatami i krzewami, przewidziano nowy układ żwirowych alejek, a place przed grobami wyłożono betonowymi płytami, wyznaczając miejsca na ławki. Warto zauważyć, że w planie zagospodarowania przestrzeni widoczne jest także łączenie istniejących grobów pojedynczych w mogiły

${ }^{86}$ Tamże, s. 123.

${ }^{87}$ Jews in Poland Form Special Committee to Restore Lublin Cemetery, „JTA Daily News Bulletin" (4 stycznia 1967).

${ }^{88}$ Jews in Poland Seek to Restore Ancient Jewish Cemetery in Lublin, „JTA Daily News Bulletin" (30 września 1965).

${ }^{89}$ APL, Wojewódzkie Zrzeszenie Gospodarki Komunalnej, sygn. 314.

${ }^{90}$ Urban, Cmentarze zydowskie..., s. 730; APL, UWL, WdsW, sygn. 353, s. 117.

${ }_{91}$ Niestety w zachowanych materiałach nie ma informacji o nazwiskach zmarłych pochowanych w grobach objętych renowacją (i łączeniem kwater).

${ }_{92}$ Informacja uzyskana od p. Romana Litmana, 12 lipca 2019. 
zbiorowe (il. 5). Być może wśród tych połączonych upamiętnień znajdują się też omawiane wcześniej pochówki z lat 1944-1947, obecnie nieczytelne w przestrzeni cmentarza. Prace objęły tylko grzebalną część cmentarza, stanowiąca jedynie stosunkowo niewielki fragment całej powierzchni jego przedwojennego obszaru. W $1968 \mathrm{r}$. na tej nekropolii pochowano szczątki ekshumowane ze zlikwidowanego i zabudowanego cmentarza żydowskiego w Puławach ${ }^{93}$, co może świadczyć o traktowaniu tego obszaru jako miejsca pamięci o Żydach z całego regionu. Konieczność uporządkowania cmentarza wynikała z bliskości rozwijającej się dzielnicy mieszkaniowej, częstych dewastacji oraz prawdopodobnie z pochowaniem na tym terenie ekshumowanych ofiar egzekucji z obszaru województwa lubelskiego.

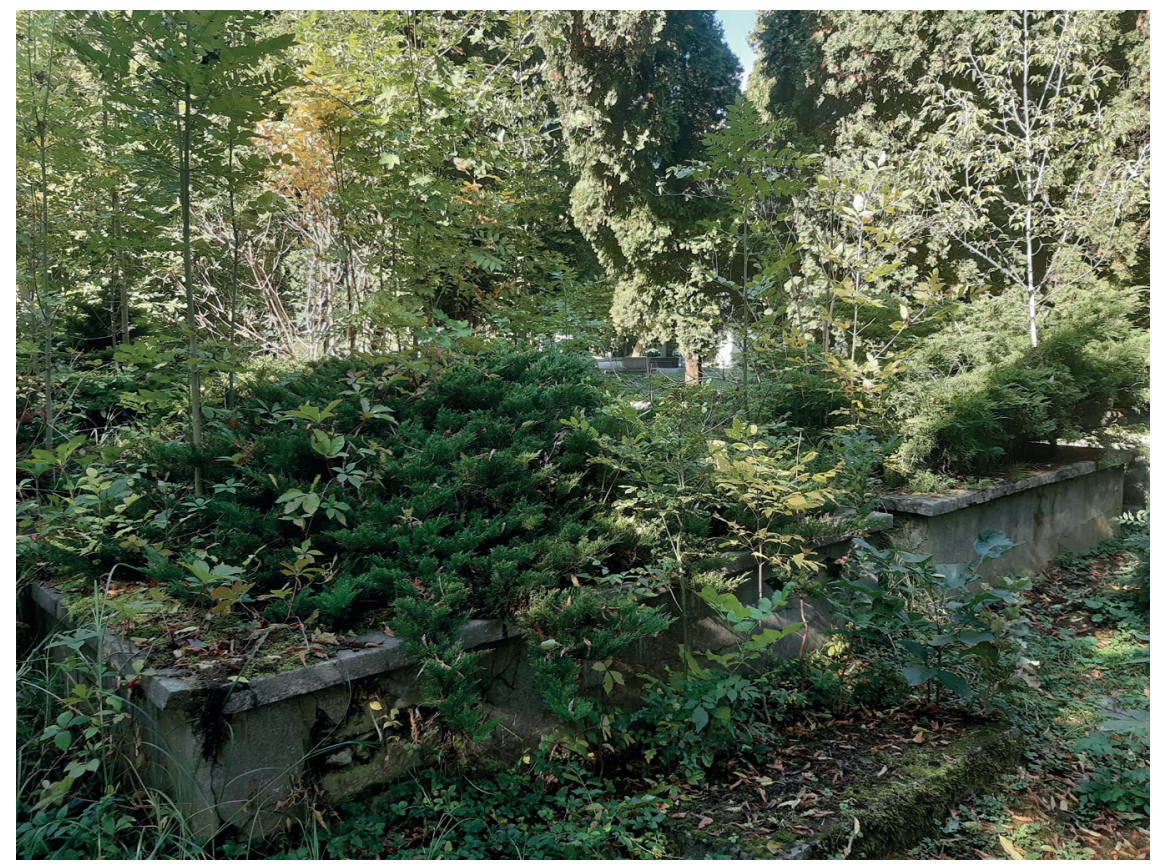

Il. 5. Przykład prawdopodobnego łączenia upamiętnień w latach sześćdziesiątych; fot. Teresa Klimowicz, 2020.

${ }^{93}$ Bielawski, Zagłada cmentarzy żydowskich ..., s. 101. 


\section{Cmentarz po wydarzeniach marcowych}

Wydarzenia marcowe $1968 \mathrm{r}$. wywarły niewątpliwie silny wpływ także na lubelską społeczność żydowską. Ponowne zawieszenie działalności Jointu, kampania antysemicka i kolejna fala migracji tworzyły atmosferę sprzyjającą dewastacji cmentarzy. W Lublinie w związku ze zmianami w planie zagospodarowania przestrzennego miasta przystąpiono do opracowania planów przecięcia cmentarza obwodnicą miejską - al. Włodzimierza Lenina (obecnie al. Generała Władysława Andersa). Było to prawdopodobnie w 1969 r., w tym samym czasie, kiedy prowadzono działania zmierzające do przecięcia cmentarza katolickiego przy ul. Unickiej ${ }^{94}$. Prace te zrealizowano ostatecznie do 1973 r. ${ }^{95}$, a w ich wyniku faktyczny teren cmentarza podzielono na dwie części (podział ten istnieje do dziś). Na południowej części znajduje się czynny cmentarz żydowski, a część północna częściowo zamieniona została na skwer (il. 6). Obszar cmentarza, z wyjątkiem przebiegu al. Andersa, nie został zabudowany, choć zaznaczyć należy, że w świetle obowiązującego prawa (Ustawy o cmentarzach i chowaniu zmarłych z 1959 r.) teren ten mógł być przeznaczony na inne cele dopiero po czterdziestu latach od ostatniego pochówku oraz po dokonaniu ekshumacji ${ }^{96}$. Oba te warunki nie zostały spełnione w przypadku omawianej przestrzeni. We wspomnieniach mieszkańców Lublina przetrwał m.in. fakt rozkopywania terenu cmentarza podczas budowy arterii. Wydobyte szczątki ludzkie (pomimo protestów środowisk żydowskich) wyrzucono w pobliskie krzaki po obu stronach drogi ${ }^{97}$, gdzie miały być widoczne jeszcze po kilku latach ${ }^{98}$. Podobną politykę planowano zastosować wobec warszawskiego cmentarza przy ul. Okopowej ${ }^{99}$.

W latach siedemdziesiątych XX w. nowy cmentarz - a w zasadzie jego użytkowana część - był w miarę uporządkowany, zwłaszcza w porównaniu

${ }^{94}$ Stanisław Santarek, Rzymskokatolicki cmentarz przy ulicy Unickiej w Lublinie, http:// unicka.cmentarz.lublin.pl/historia/ [dostęp: 12 października 2019].

95 Aleja Lenina - pusto, „Kurier Lubelski” (2 sierpnia 1973), s. 4.

${ }_{96}$ Bednarek, Sytuacja prawna..., s. 194.

${ }_{97}$ Relacja Mariana Wojtasa, 20 marca 2018, rozmawiał Tomasz Czajkowski, OBGTNN; Relacja Morrisa Wajsbrota, 29 listopada 2010, rozmawiał Tomasz Czajkowski, red. Maria Radek, OBGTNN.

${ }_{98}$ Informacja od członkagrupyna portalu Facebookpod nazwą, ,UroczyLublin”, zamieszczona przez Jarosława Szczuryka vel Szczerbę dnia 9 grudnia 2019 r., https://www.facebook. com/groups/uroczy.lublin/3075705082459589/?comment_id=3076679325695498\&notif_ id $=1575897905873325 \&$ notif_t $=$ group_comment\&ref=notif [dostęp: 9 grudnia 2019].

99 Bielawski, Zagłada cmentarzy żydowskich..., s. 80. 


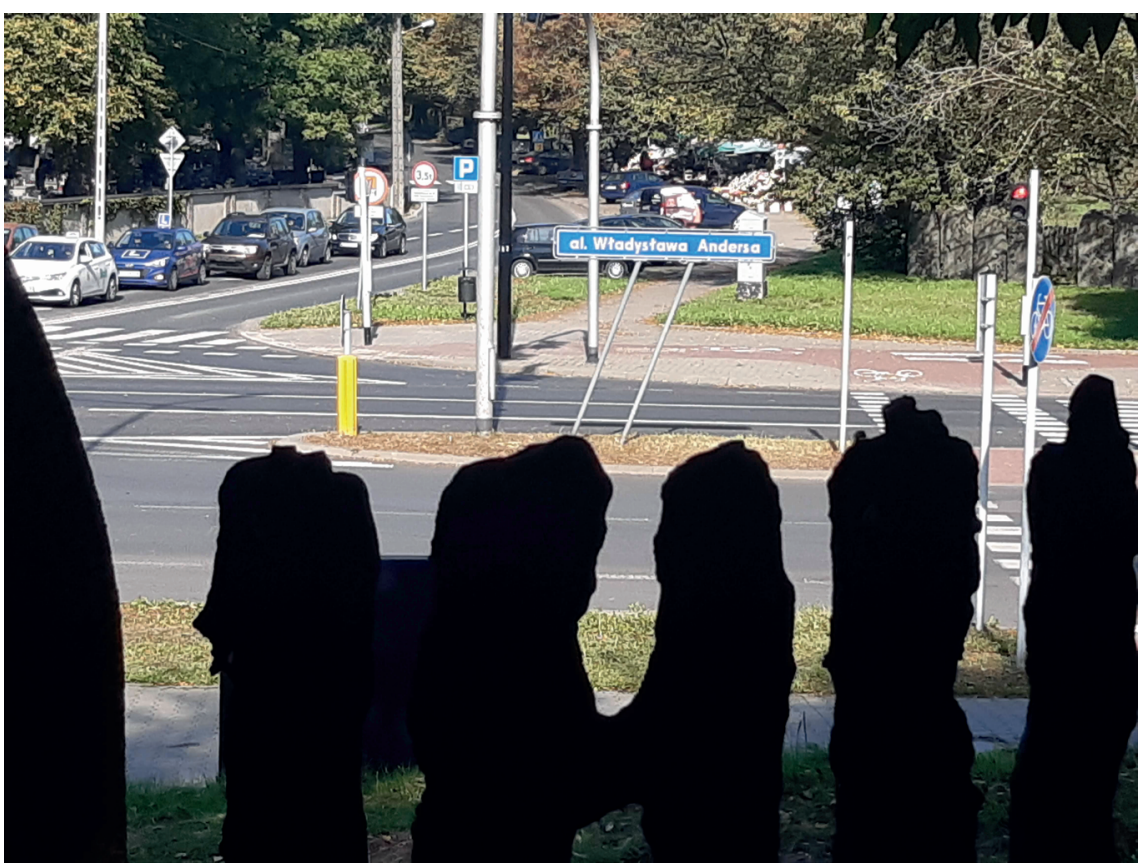

Il. 6. Przebieg al. Władysława Andersa przez teren cmentarza żydowskiego; fot. Teresa Klimowicz, 2020.

do starego cmentarza żydowskiego przy ul. Siennej, który w owym czasie planowano oddać na potrzeby Muzeum Wsi Lubelskiej. Jednak już w 1976 r. na łamach gazety „Kol Lublin”, wydawanej przez Ziomkostwo Lubelskie, co jakiś czas pojawiały się głosy wzywające do uporządkowania starego cmentarza ${ }^{100}$, nie było jednak podobnych apeli w odniesieniu do omawianego nowego cmentarza. Ta zagraniczna aktywność była prawdopodobnie związana z działalnością rabina Isaaca Lewina prowadzoną od 1974 r. w Stanach Zjednoczonych na rzecz polskiego ZRWM i samych cmentarzy jako zabytków kultury żydowskiej ${ }^{101}$.

Na kondycję nowego cmentarza miały wpływ różnego rodzaju problemy finansowe i społeczne, omawiane na spotkaniach Kongregacji Wyznaniowej. W protokole z zebrania z 1978 r. można przeczytać, że Kongregacja czyniła starania celem utrzymania należytego stanu cmentarza, pielenia chwastów i pielęgnacji krzewów, co jednak napotykało nie tylko trudności

100 Aron Nissenbaum, A bezuch in Lublin on in Warsze, „Kol Lublin” (1976), nr 11, s. 14.

${ }^{101}$ Sommer Schneider, Sze'erit hapleta..., s. 336-337. 
finansowe, lecz było także problematyczne ze względu na brak chętnych do tego typu prac. Odnotowywano też pogorszenie stanu zachowania nagrobków. W protokole zapisano:

W swoim czasie wykonane były roboty mające na celu doprowadzenie nagrobków i innych urządzeń do porządku i estetycznego wyglądu. Ostatnio stan ten uległ pogorszeniu, tak ze względu na oddziaływania atmosferyczne w związku z upływem czasu, jak również w wyniku wyczynów chuligańskich ${ }^{102}$.

Zwracano też uwagę na konieczność pozyskania środków na naprawę zdewastowanych nagrobków oraz obelisku przy grobach ofiar hitleryzmu. Podkreślano także, że cmentarz ten jest miejscem dorocznych, odbywających się w listopadzie upamiętnień: „zapalenia zniczy, odprawienia nabożeństwa i wygłoszenia zredagowanego do tego celu przemówienia żałobnego" ${ }^{103}$. Próbując zatrzeć złe wrażenie pozostałe po wydarzeniach marcowych, traktowano zatem cmentarz jako przestrzeń wydarzeń o charakterze propagandowym, nie dbając jednak w istocie o godny spoczynek pochowanych tam osób. W maju 1978 r.w sprawie cmentarza interweniował też centralny oddział Kongregacji, wyrażając negatywne stanowisko wobec planów Wydziału Gospodarki Terenowej i Ochrony Środowiska dotyczących nasypania ziemi i zamiany obszaru cmentarza na zieleniec ${ }^{104}$ (zdarzało się tak jednak - co najmniej od czasu budowy al. Lenina). W odpowiedzi na sprzeciw Wydział informował w czerwcu tego roku, że teren został "jedynie uporządkowany wraz z wyznaczeniem ciągów pieszych", choć praktycznie był użytkowany jako skwerek rekreacyjny. Wydział wytykał też zły stan cmentarza Kongregacji Wyznaniowej, która - prawdopodobnie jako właściciel i zarządca terenu - miała obowiązek utrzymywania tego miejsca w należytym porządku. W przytaczanym piśmie pojawia się jednocześnie informacja o ciągle występującej profanacji i zakłócaniu spokoju zmarłym przez „elementy chuligańskie i przestępcze” ${ }^{105}$.

Od 1979 r. Wydziały ds. Wyznań rozpoczęły zbieranie danych dotyczących „opuszczonego mienia pożydowskiego”, pytając m.in. o stan zachowania i sposób użytkowania cmentarzy - czy teren jest koszony? kto zawierał umowy w tej sprawie? itd. Było to związane z inwentaryzacją stanu zachowania, ale też kontrolą stanu posiadania - czy oddany na rzecz praktyk wyznaniowych majątek Skarbu Państwa nie jest przypadkiem

\footnotetext{
102 APL, UWL, WdsW, sygn. 353, s. 173.

103 Tamże.

104 Tamże, s. 186.

105 Tamże, s. 188.
} 
użytkowany w innych celach ${ }^{106}$. Wydział Gospodarki Terenowej i Ochrony Środowiska w Lublinie informował w odpowiedzi, że cmentarz żydowski przy ul. Walecznych ma powierzchnię 8,6 ha, z czego wydzielono część czynną o powierzchni 0,528 ha, która jest w całości własnością miejscowej Kongregacji Wyznaniowej. Znajduje się tam także informacja, że nieużytkowana część cmentarza została przeznaczona na zieleń parkową, której utworzenie będzie możliwe po przejęciu we władanie tego terenu przez Skarb Państwa ${ }^{107}$. Interwencje centralnych władz Kongregacji, jak i władz administracji państwowej w tej sprawie były najprawdopodobniej związane z próbą zmniejszenia napięcia ze Stanami Zjednoczonymi, a kwestia stanu dziedzictwa żydowskiego w Polsce stała się elementem wizerunku Polski w relacjach międzynarodowych.

\section{Lata osiemdziesiąte}

Lata osiemdziesiąte $\mathrm{XX}$ w. przyniosły przede wszystkim zmianę sytuacji politycznej w Polsce. Efektem tej zmiany było m.in. dążenie do poprawy wizerunku kraju, także przez ponowne otwarcie na współpracę z Jointem. W kwietniu 1980 r. na konferencji w Halinie (pod Warszawą) doszło do zawarcia porozumienia między Ministerstwem Kultury i Sztuki, Urzędem ds. Wyznań, Ministerstwem Administracji, Gospodarki Terenowej i Ochrony Środowiska oraz Stowarzyszeniem PAX w sprawie podjęcia działań zmierzających do ochrony zabytkowych cmentarzy, w tym cmentarzy żydowskich ${ }^{108}$. Na początku lat osiemdziesiątych Urząd ds. Wyznań sporządził raport dotyczący stanu cmentarzy wyznania mojżeszowego, rekomendując także działania związane z porządkowaniem i ogrodzeniem cmentarzy żydowskich, co stało się też elementem wytycznych zawartych w porozumieniu o współpracy z Jointem w $1981 \mathrm{r} \cdot{ }^{109} \mathrm{~W}$ raporcie tym stan cmentarza przy ul. Walecznych określono następująco:

Nieliczne resztki zdewastowanego muru (15\%). Kwatera czynna i kwatera martyrologii odgrodzone od reszty terenu żywopłotem i częściowo murem. Pozostały teren zachwaszczony. Kilka kamiennych nagrobków poprzewracano, mauzoleum Rabina Szapiro ${ }^{110}$.

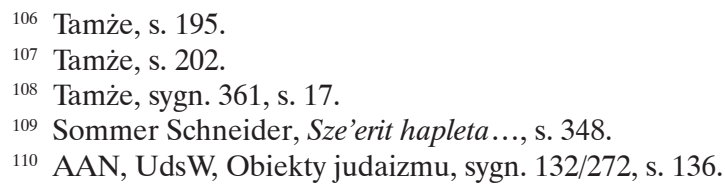


Widać zatem, że monitorowano stan cmentarza jako czynnego miejsca pochówku. Warto podkreślić także, iż część cmentarza uważano za miejsce martyrologii i ogrodzono żywopłotem. Prawdopodobnie chodzi o tę część, na której pochowano ofiary getta na Majdanie Tatarskim. Teren cmentarza był też najwyraźniej dewastowany, odnotowano również informację o istnieniu ohelu Majera Szapiry, nie wzmiankując jednak, że w latach osiemdziesiątych XX w. jego grób w tym miejscu był już pusty.

W efekcie zmiany polityki władz centralnych, które zaczęły postrzegać sprawę cmentarzy żydowskich jako polityczną już w połowie lat siedemdziesiątych, na początku lat osiemdziesiątych odsłonięto na cmentarzu żydowskim przy ul. Walecznych pamiątkową tablicę ${ }^{111}$. Prawdopodobnie była to zarazem jedna z pierwszych aktywności pochodzącego z Piasków Luterskich, ale wychowującego się w Lublinie, Symchy Wajsa, lekarza stomatologa, który był inicjatorem kilkunastu upamiętnień społeczności żydowskiej Lublina w latach osiemdziesiątych i dziewięćdziesiątych XX w. ${ }^{112}$

W piśmie z 1981 r. informowano także o opiece sprawowanej przez Wydział Gospodarki Terenowej i Ochrony Środowiska nad kwaterą martyrologiczną czynnej części cmentarza oraz o planach jej generalnego remontu w latach 1982-1984 ${ }^{113}$. Rzeczywiście podjęto krokiw tym kierunku już pod koniec 1981 r., konsultując działania z centralą ZRWM. W marcu następnego roku ZRWM wyraził zgodę na realizację planowanych prac, dając jednocześnie wskazówki dotyczące formy upamiętnienia (wybór padł na pomnik w kształcie menory, sugerowano jednak by miał on rozmiar mniejszy niż projektowane $7 \mathrm{~m}$ wysokości). Podkreślano także, aby planowane nasadzenia zieleni „miały charakter cmentarny” - żeby nie były to np. kwietniki ${ }^{114}$.

Jednak już w maju 1982 r. ZRWM apelował do lokalnych władz o nadzór nad terenem cmentarza, który wciąż był regularnie dewastowany ${ }^{115}$. W odpowiedzi Wydział Gospodarki Terenowej i Ochrony Środowiska zwracał uwagę, że stan cmentarza sprzyja dewastacjom przez „grupki chuligańskie" oraz że jest to teren należący do miejscowej Kongregacji Wyznaniowej, który był latami zaniedbywany i jest zarośnięty krzakami, obarczając tym samym odpowiedzialnością za zaistniałą sytuację dys-

111 jb, Nie wolno zapomnieć, „Kurier Lubelski” (21 września 1984), s. 8.

112 Zob. Symcha Wajs (1911-1999), [w:] Sylwetki Żydów lubelskich. Leksykon, red. Adam Kopciowski i in., Lublin 2019, s. 271.

${ }_{113}$ APL, UWL, WdsW, sygn. 353, s. 226.

114 Tamże, s. 231.

115 Tamże, s. 232. 
ponenta nekropolii. Jednocześnie poinformowano, że Wydział zwrócił się do Milicji Obywatelskiej o zwiększenie patroli na terenie cmentarza, sugerując, że na zaprzestanie dewastacji wpłynie planowane uporządkowanie tego obszaru ${ }^{116}$.

Również w roku następnym na kilku cmentarzach żydowskich w regionie prowadzono działania porządkowe, które zlecone były przez wojewodę lubelskiego z okazji rocznicy powstania w getcie warszawskim ${ }^{117}$. W ramach tych prac planowano także działania na cmentarzu przy ul. Walecznych. Zatwierdzenie planów porządkowych miało nastąpić do października 1983 r. ${ }^{118}$ Miały one zostać sfinansowane ze środków budżetu terenowego w kwocie 6 mln zł przy jednoczesnym zaplanowaniu $2 \mathrm{mln}$ zł rocznie na bieżącą pielęgnację ${ }^{119}$. W roku następnym na renowację kwatery martyrologii ludności żydowskiej przeznaczono $1,5 \mathrm{mln} \mathrm{z}^{120}$.

Akcję inwentaryzowania i remontów cmentarzy żydowskich kontynuowano także w 1985 r. Pojawiają się wówczas informacje o planowanym rozpoczęciu prac na omawianej nekropolii w drugim kwartale tego roku ${ }^{121}$ oraz o ich przewidywanym zakończeniu w 1987 r. Środki na ten cel miały być przeznaczone z funduszy remontów kapitalnych i grobownictwa wojennego ${ }^{122}$. O pilnej potrzebie interwencji w kondycję cmentarza świadczyć może skierowana w maju 1985 r. przez Kongregację Wyznaniową prośba do prezydenta Lublina. Jej przewodniczący, Matys Zoberman, pisał następująco:

Od dłuższego czasu, a nasiliło się to ostatnio, dewastowane są nagrobki osób pochowanych na tym cmentarzu. Dewastacje te polegają na usuwaniu bądź przesuwaniu płyt nagrobnych, ich tłuczeniu, uszkadzaniu postumentów, usuwaniu tablic itp. Doszło do tego, że na tym cmentarzu nie ma ani jednego nieuszkodzonego grobu. Ostatnio ludzie z marginesu społecznego wykorzystują teren cmentarza na miejsce schadzek i urządzania libacji alkoholowych. Potrzeby fizjologiczne załatwiane są na grobach. Dzieje się tak w dzień i wieczorem, zaś osoby odwiedza-

116 Tamże, s. 234.

117 Tamże, s. 236-257.

118 Czynności te mogły być związane także z początkami działalności Fundacji Rodziny Nissenbaumów i z powstaniem w sierpniu 1983 r. Międzynarodowej Komisji ds. Cmentarzy Żydowskich w Polsce, w której skład weszli przedstawiciele władz administracyjnych i środowisk żydowskich, por. Bielawski, Zagłada cmentarzy żydowskich..., s. 116.

119 APL, UWL, WdsW, sygn. 353, s. 262.

120 Tamże, s. 288.

121 Tamże, s. 298.

122 Tamże, s. 305. 
jące ten cmentarz narażone są na systematyczne zaczepki i wulgarne wyzwiska. Rodziny zmarłych w tej sytuacji obawiają się odwiedzać groby swych bliskich ${ }^{123}$.

Kongregacja zwracała się tym samym z prośbą o zapewnienie ochrony przez odpowiednie służby. W odpowiedzi prezydent miasta wezwał z kolei lubelski oddział Kongregacji do uporządkowania terenu cmentarza, informując, że miasto obejmuje opieką jedynie teren kwatery martyrologicznej:

W ramach powyższego corocznie konserwuje się zieleń, a z okolicznościowych okazji składane są kwiaty i palone znicze. Efekty tych działań są jednak niewidoczne z powodu braku zagospodarowania, utrzymania w należytym porządku i nadzoru na pozostałej części cmentarza (ok. 90\% powierzchni) ${ }^{124}$.

Od połowy lat osiemdziesiątych XX w. Polskę wizytowały rozmaite delegacje zagraniczne, wywierając nacisk na politykę społeczności żydowskiej w związku ze stanem żydowskich zabytków. W lipcu 1986 r. doszło do spotkania władz miasta z przedstawicielami społeczności żydowskiej z Belgii i Izraela, w tym z Manfredem Frenklem, którego udział w staraniach o zachowanie omawianego cmentarza okazał się najistotniejszy. Na spotkaniu omawiano stan obu lubelskich cmentarzy żydowskich. Pojawiła się też idea założenia organizacji opiekującej się cmentarzami, dyskutowano plany władz i sposób zagospodarowania terenu nekropolii, przy czym zagraniczni goście zgłosili własną koncepcję urządzenia tego miejsca. Zaproponowano ogrodzenie południowego fragmentu dawnego cmentarza, a nie tylko małej, czynnej części, budowę budynku dla dozorcy oraz niewielkiego muzeum judaizmu. Sugerowano także zrezygnowanie z obsadzania zielenią i częściowe ogrodzenie terenu cmentarza znajdującego się po północnej stronie al. Lenina ${ }^{125}$. W przypadku spełnienia tych żądań Manfred Frenkel zadeklarował opłacenie renowacji, a nawet zwrot poniesionych przez miasto kosztów.

W październiku 1986 r. „Kurier Lubelski” donosił także o planowanych pracach porządkowych na cmentarzu przy ul. Walecznych, które miały być sfinansowane tym razem przez Związek Religijny Wyznania Mojżeszowego ${ }^{126}$. Związek upominał się wtedy - w piśmie skierowanym do prezydenta Lublina ${ }^{127}$ - o objęcie ochroną terenu położonego po pół-

123 Tamże, s. 327.

${ }^{124}$ Tamże, sygn. 354, s. 34.

${ }^{125}$ Tamże, s. 19.

${ }^{126}$ Porzadkowanie żydowskich cmentarzy, „Kurier Lubelski” (16 października 1986), s. 4.

127 Pismo ZRWM do Prezydenta Miasta Lublina z 16 lipca 1986 r., OBGTNN, Dokumentacja Fundacji Sary i Manfreda Frenklów ze zbiorów Tomasza Przeciechowskiego, s. 22. 
nocnej stronie ówczesnej al. Lenina (użytkowanej jako skwer), wnosząc o zmianę planów zagospodarowania przestrzeni. Powoływano się przy tym na fakt, że przestrzeń ta była miejscem rozstrzeliwań Żydów w czasie II wojny światowej ${ }^{128}$. Była to prawdopodobnie próba wprowadzenia w życie zamierzeń Manfreda Frenkla za pośrednictwem ZRWM, o czym świadczyć może podobieństwo zaprezentowanej koncepcji rewaloryzacji cmentarza przedstawionej w piśmie ZRWM do wojewody lubelskiego kilka miesięcy wcześniej (w lipcu). Plany rewaloryzacji cmentarza roztaczane przez ZRWM obejmowały remont oraz odtworzenie ogrodzeń i alei wewnętrznych, budowę bramy głównej przy ul. Walecznych oraz budynku o przeznaczeniu muzealnym i administracyjno-rytualnym, urządzenie parkingów i ciągów pieszych. Odwoływano się także do poszanowania zasad religijnych (zasada nienaruszalności grobów) w odniesieniu do tworzenia ciągów komunikacyjnych oraz obsadzania zielenią ${ }^{129}$. W październiku, jeszcze przed ukazaniem się wspomnianego wcześniej artykułu w „Kurierze Lubelskim”, prace jednak utknęły z uwagi na konieczność dokonania zmian w planie zagospodarowania przestrzennego ${ }^{130}$.

Zakres i sposób zagospodarowania nowego cmentarza był w owym czasie przedmiotem zainteresowań władz lokalnych, które dążyły jednak do uzyskania deklaracji od ZRWM w sprawie opieki i finansowania obu cmentarzy żydowskich $^{131}$. Celem nadania dalszego biegu sprawie Urząd Wojewódzki zażądał specjalistycznego opracowania historycznego. Przeprowadzone w marcu 1987 r. badanie terenu nekropolii na potrzeby Biura Dokumentacji Zabytków ${ }^{132}$ wskazywało, że część po północnej stronie al. Lenina wykorzystywana była jako prowizoryczny parking, część południowa zaś ,jest nadal użytkowana [do celów grzebalnych] i z tego względu nie może być przeznaczona na tereny zielone". Krzysztof Marciszuk, autor opracowania, wspomina także o zachowanym fragmencie oryginalnej części ogrodzenia od strony wschodniej. Mur ten opisany został jako „ceglany szereg ślepych arkad”. Odnotowuje również zachowanie części ogrodzenia (il. 7), które datuje na rok 1830, choć należy raczej przypuszczać, że jest to mur ufundowany przez Ziomkostwo już w latach powojennych (o czym była mowa wcześniej). Marciszuk wymienia także jeden zachowany nagrobek

${ }^{128}$ Wydaje się, że chodzi tu o część na północ od al. Lenina. Por. APL, UWL, UdsW, sygn. 354, s. 25.

129 Tamże.

${ }_{130}$ Tamże, s. 67.

${ }_{131}$ Tamże, s. 66-69.

132 Marciszuk, Cmentarz żydowski przy ul. Walecznych..., s. 5. 
z okresu przedwojennego (fotografię zamieszczono w opracowaniu) oraz wspomina o istniejącym na terenie czynnego cmentarza ohelu Majera Szapiry, odrestaurowanym - jego zdaniem - w latach sześćdziesiątych XX w., jak również o mogiłach zbiorowych. Część grzebalna, zgodnie z opisem, obsadzona została żywotnikami. Stan zieleni na terenie cmentarza oceniał jako mocno zaniedbany:

Zieleń na cmentarzu, podobnie jak i nagrobki, nie jest pielęgnowana. [...] Zaniedbana szata roślinna sprawia, że obiekt nie posiada żadnego znaczenia w krajobrazie tej części miasta. [...] Współczesne nagrobki i mogiły są zaniedbane i zdewastowane. $\mathrm{Z}$ uwagi na brak ogrodzenia cmentarz jest nadal zaśmiecany i niszczony ${ }^{133}$.

Co ciekawe, autor charakteryzuje także społeczność żydowską, określając ją jako nieliczną i niezwiązaną ze środowiskiem lubelskim. W zaleceniach konserwatorskich wskazuje ponadto podmioty, które powinny wziąć odpowiedzialność za kondycję nekropolii: za stan cmentarza powinni odpowiadać Polacy żydowskiego pochodzenia oraz władze miasta. Sugeruje, że

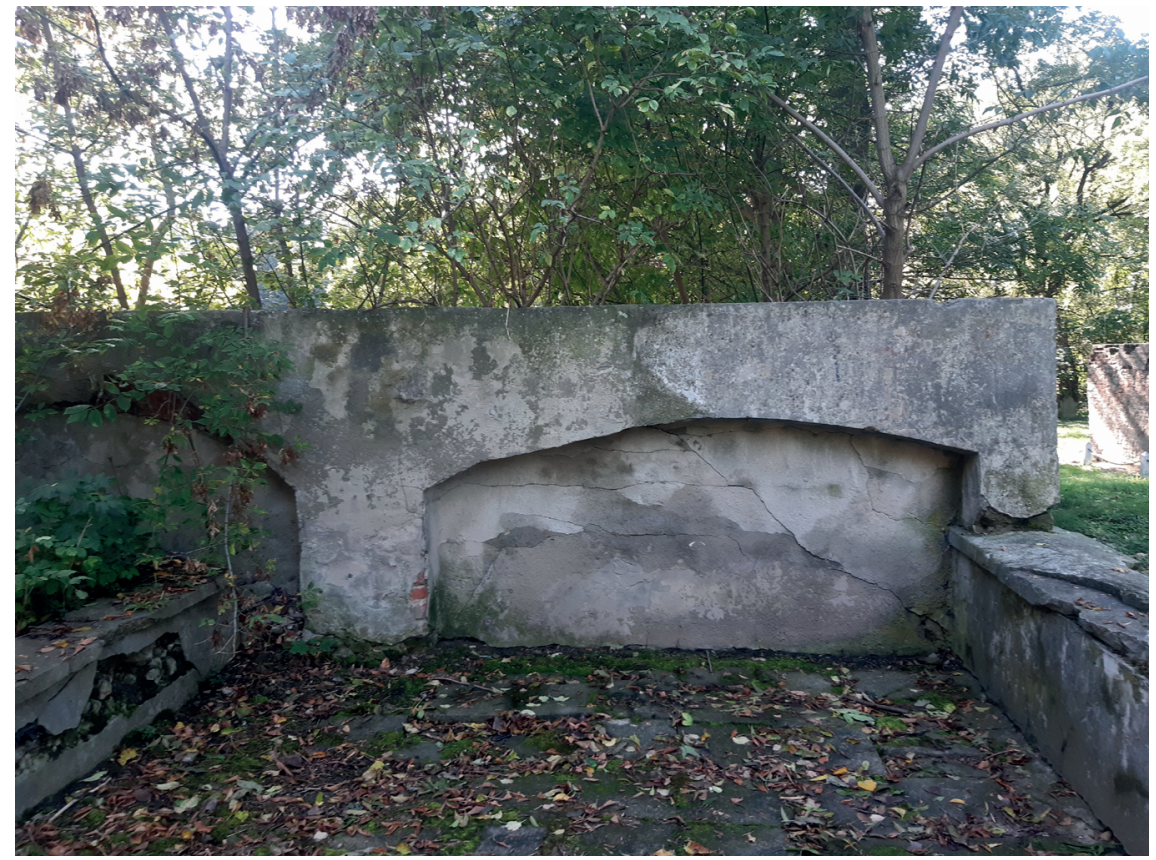

Il. 7. Fragment muru cmentarza żydowskiego; fot. Teresa Klimowicz, 2020.

133 Tamże, s. 7. 
środki finansowe na ten cel mógłby uzyskać Związek Religijny Wyznania Mojżeszowego dzięki wsparciu Światowego Kongresu Żydów, jeśli zgodzą się na to władze państwowe. Wskazano także konieczność odbudowy ogrodzenia i wstawienia kutej bramy z symbolami żydowskiej sztuki sepulkralnej. Pojawia się także postulat utworzenia synagogi-muzeum, której umiejscowienie proponowane jest po północnej stronie al. Lenina (dziś al. Andersa, a zatem na terenie zamkniętej części cmentarza użytkowanej jako parking i skwer $)^{134}$. Takie rozwiązania proponowano też w piśmie ZRWM do wojewody lubelskiego ${ }^{135}$. Z dokumentów dotyczących zagospodarowania terenu cmentarza z 1987 r. wynika, że został on podzielony na dwie części, z których południową - wraz z terenem, gdzie nadal dokonywano pochówków - objęto ochroną konserwatorską. Obszar północny natomiast przeznaczono na „zieleń parkową”. W piśmie zaznaczono jednak, że ze względu na bliskość osiedli mieszkaniowych teren powinien być obsadzony „wysoką zielenią" ${ }^{136}$.

W 45. rocznicę likwidacji lubelskiego getta ${ }^{137}, 9$ listopada 1987 r., przy finansowym wsparciu Urzędu Miasta w Lublinie odsłonięto drugi monument na terenie cmentarza, nazwany pomnikiem Pamięci Ofiar Getta i Zwycięstwa nad Faszyzmem. Został on zaprojektowany przez Sławomira Mieleszkę w kształcie stylizowanej menory stojącej na wysokim słupie zdobionym zarysami postaci ludzkich (il. 8) ${ }^{138}$. Pomnik ten znajduje się w czynnej części cmentarza, tuż obok masowej mogiły, w której pochowano - jak wspomniałam wcześniej - ciała dzieci z żydowskiej ochronki przy ul. Grodzkiej. W organizację obchodów 45. rocznicy likwidacji getta lubelskiego (program uroczystości był bogaty, ale - poza odsłonięciem pomnika - niezwiązany z omawianym cmentarzem) zaangażowani byli przedstawiciele społeczności żydowskiej, jak Marian Adler i Symcha Wajs, a także lubelscy badacze kultury żydowskiej - Zygmunt Mańkowski i Andrzej Trzciński ${ }^{139}$.

134 Tamże, s. 7-8.

135 APL, UWL, WdsW, sygn. 354, s. 31.

136 Załącznik nr 2 do wskazań lokalizacyjnych z dnia 27 listopada 1987 r., OBGTNN, Dokumentacja Fundacji Sary i Manfreda Frenklów ze zbiorów Tomasza Przeciechowskiego, s. 23-24.

137 Chodzi o datę likwidacji getta na Majdanie Tatarskim 9 listopada 1942 r., por. AAN, UdsW, sygn. 132/264, s. 33.

${ }_{138} \dot{Z} y d z i$ lubelscy $i$ ich cmentarze [ulotka prawdopodobnie autorstwa Andrzeja Trzcińskiego, powstała po 1989 r.], OBGTNN, Archiwum Hanny Wyszkowskiej, teczka V, b.p.; por. Marta Kubiszyn, Niepamięć - postpamięć - wspótpamięć. Zagłada lubelskich Żydów jako przedmiot kultury pamięci, Lublin 2019, s. 152.

139 APL, UWL, WdsW, sygn. 354, s. 72. 


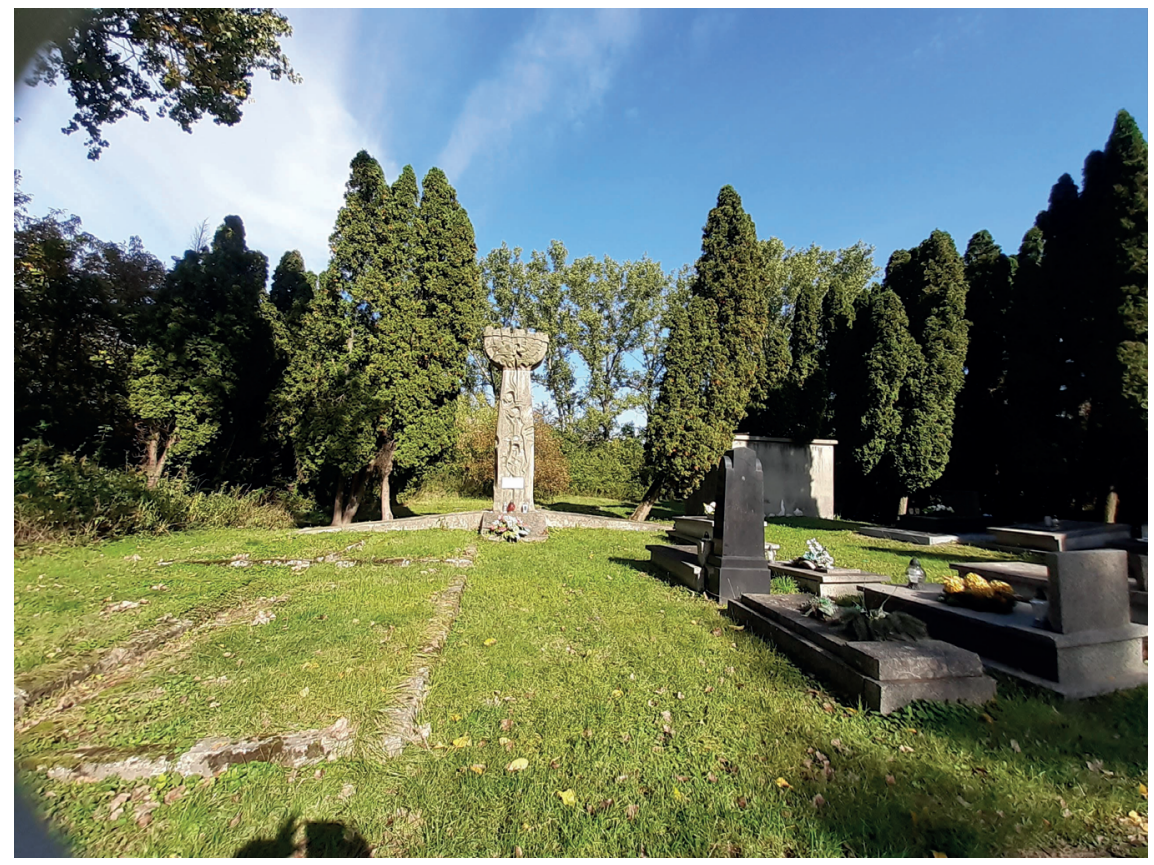

Il. 8. Pomnik Pamięci Ofiar Getta i Zwycięstwa nad Faszyzmem; fot. Teresa Klimowicz, 2020 .

W kwietniu 1988 r. podczas prac budowlanych przy ul. Pogodnej odkryto zbiorową mogiłę z czasów II wojny światowej. Był to teren getta na Majdanie Tatarskim. Znalezione szczątki wzbudziły uwagę okolicznych mieszkańców, którzy - jak donosił „Kurier Lubelski” - przekopywali grób w poszukiwaniu kosztowności ${ }^{140}$. Pochówku odnalezionych wówczas szczątków 190 osób dokonano 26 lipca 1990 r. na nekropolii żydowskiej przy ul. Walecznych ${ }^{141}$, a w zasadzie na terenie cmentarza z czasów I wojny światowej, uznawanego za kwaterę martyrologiczną. Ważnym wydarzeniem dla omawianego zagadnienia było utworzenie 3 listopada 1988 r. Fundacji Sary i Manfreda Frenklów, żydowskiego małżeństwa mieszkającego w Antwerpii. Sara Bass-Frenkel pochodzi z Lublina, a w czasie likwidacji getta lubelskiego ukrywała się wraz z siostrą właśnie na cmentarzu

140 Ziemia $ł k a$, „Kurier Lubelski” (19 kwietnia 1988), s. 1, 4.

${ }^{141}$ Grzegorz Wójcikowski, Włodzimierz Wójcikowski, Kalendarium, [w:] Tadeusz Radzik, Wiesław Śladkowski, Grzegorz Wójcikowski, Włodzimierz Wójcikowski, Lublin. Dzieje miasta. T. 2: XIX i XX wiek, Lublin 2000, s. 577. 
przy ul. Walecznych. Udało im się przetrwać dzięki pomocy księdza Jana Poddębniaka, który załatwił młodym dziewczynom fałszywe dokumenty. Posługując się nimi, jako Stanisława Gorczyca i Maria Taracha wyjechały na roboty do Niemiec.

Sara Bass i Manfred Frenkel pobrali się w 1945 r., wyemigrowali razem najpierw do Izraela, a następnie osiedli w Belgii, gdzie prowadzili zakład związany z obróbką diamentów. Małżeństwo podjęło starania o zachowanie lubelskiego cmentarza już dwa lata wcześniej, udało się jednak je formalnie sfinalizować w 1988 r. Powołano wówczas w Lublinie Fundację zajmującą się opieką nad cmentarzami żydowskimi, choć przede wszystkim nad miejscowym, nowym cmentarzem. Pełnomocnikiem Fundacji został adwokat lubelski Tomasz Przeciechowski. 9 listopada 1988 r. ogłoszono plany budowy upamiętnienia oraz wmurowano kamień węgielny z okazji 46. rocznicy likwidacji getta lubelskiego. Prace nad rewaloryzacją cmentarza zlecono firmie Tender. Jak donosił „Kurier Lubelski”, przedstawione przez Stanisława Machnika założenie architektoniczne miało być przedsięwzięciem unikatowym w skali kraju:

Kirkut [...] będzie miał ogrodzenie w kształcie macew (płyty nagrobne, które na cmentarzach żydowskich ustawia się pionowo) o wysokości 1,70 m i menor (7-ramienne świeczniki) o wysokości 1,20 m. Za ogrodzeniem, na terenie kirkutu, stanie dwupoziomowy obiekt z żelbetonu, wyłożony granitem. Na parterze pomieści izbę modlitw, a na górze izbę pamięci ${ }^{142}$.

Prace planowano zakończyć w listopadzie 1989 r. Niestety trudności finansowe i formalne spowodowały przerwanie prac na cmentarzu w kwietniu 1989 r. ${ }^{143}$ Problemem były rosnące koszty po stronie wykonawcy oraz trudności związane $\mathrm{z}$ wypełnianiem warunków formalnych związanych z działalnością Fundacji. Postępy prac z zainteresowaniem śledziła lokalna prasa.

Działalność Fundacji Frenklów była także przyczyną rosnącego zainteresowania cmentarzem ze strony władz, a także przesłanką do objęcia ochroną konserwatorską całości terenu przedwojennego cmentarza, po obu stronach al. Lenina. Jego wpisu do rejestru zabytków pod pozycją A/983 dokonano 11 sierpnia $1989 \mathrm{r}$. W sierpniu tego samego roku na terenie remontowanej nekropolii zjawiła się delegacja, w której skład wchodzili: izraelski minister ds. religii Zewulun Hammer, Naczelny Rabin

142 Kirkut przy ul. Walecznych w listopadzie, „Kurier Lubelski” (8 marca 1989), s. 8.

143 AAN, UdsW, sygn. 132/264, s. 49. 
Polski Pinchas Menachem Joskowicz oraz dyrektor zespołu ds. nierzymskokatolickich kościołów i związków wyznaniowych przy Ministerstwie ds. Wyznań - Grzegorz Rydlewski ${ }^{144}$.

\section{Upamiętnienia początku lat dziewięćdziesiątych}

Okres transformacji ustrojowej przyniósł także zmiany w podejściu do cmentarzy żydowskich. W sensie prawnym stały się one własnością komunalną, politycznie zaś uznano, przynajmniej deklaratywnie, sakralny status tych cmentarzy w judaizmie. Cmentarz pozostawał jednak nadal przestrzenią performowania polityki historycznej. 26 lipca 1990 r. na nowym cmentarzu - jak wspomniano już wcześniej - odbył się pochówek szczątków ofiar getta na Majdanie Tatarskim odnalezionych w 1988 r. Liczbę ofiar ustalono na 190. W jednej z lokalnych gazet ukazał się wówczas artykuł opisujący tę ceremonię 145 :

Wśród zgromadzonych na cmentarzu byli obecni przedstawiciele władz wojewódzkich i miejskich Lublina, przyszła również garstka starych Żydów, zaledwie minjan (10 osób). Tylu bowiem zostało sponad [sic!'] czterdziestotysięcznej społeczności żydowskiej w Lublinie ${ }^{146}$.

W artykule wymieniono także nazwiska (prawdopodobnie mocno zniekształcone) dwunastu ofiar: Brot Szyja, Gordon (brak imienia), Grajek Szolik $^{147}$, Kawa Bronka, Kawa Regina, Less, lekarka z Lublina, Less, dziecko lekarki, Naj Ela, Silberlicht, Sturm (brak imienia) ${ }^{148}$. Ponadto, w spuściźnie, którą pozostawił wspominany już Symcha Wajs, zachowało się także wygłoszone z tej okazji przemówienie:

Szanowni zebrani,

Przybyliśmy tu, by pogrzebać szczątki 190 osób na tym oto cmentarzu i w tym oto miejscu. Długie były badania śledcze (przeszło 2 lata), ale niezbicie wykazały, że są to kości ludzkie znalezione na terenie byłego getta na Majdanie Tatarskim. [...] $\mathrm{xxx}$

W 1946 roku na byłym terenie getta na Majdanie Tatarskim odnaleziono szczątki kilkudziesięciu Żydów zamordowanych tamże. Było to 11 grudnia 1946 roku.

${ }_{144}$ Minister Hammer o kirkucie na Siennej, „Kurier Lubelski” (25-27 sierpnia 1989), s. 1.

145 Por. Bielawski, Zagłada cmentarzy żydowskich ..., s. 119.

${ }^{146}$ Wycinek z „Kuriera Lubelskiego”, OBGTNN, Archiwum Symchy Wajsa, teczka X, b.p.

147 Chodzi prawdopodobnie o Szamę Grajera.

148 Wycinek z „Kuriera Lubelskiego”... 
Ekshumowano wówczas 70 osób i pochowano na żydowskim cmentarzu we wspólnej mogile.

W kwietniu 1988 roku podczas prac budowlanych na terenie Majdanu Tatarskiego odkryto szczątki 190 osób, w tym szczątki małych dzieci zamordowanych przez faszystów niemieckich. [...] Hitlerowi nie udało się nas wymordować. Mimo wielkich olbrzymich strat - zamordowano w bestialski sposób 6 milionów Żydów, w tym ponad 3 miliony z Polski - NARÓD ŻYDOWSKI ŻYJE! AM ISRAEL CHAJ! ${ }^{149}$.

Pogrzeb szczątków ofiar odkrytego w latach osiemdziesiątych XX w. grobu rozdrapywał zapewne wojenne rany i zmuszał do konfrontacji z przeszłością. Pogrzeb ten, przeprowadzony z całym ceremoniałem i w obecności prasy, był też niewątpliwie politycznym gestem - zarówno ze strony władz, jak i członków społeczności żydowskiej. Triumfalny okrzyk Symchy Wajsa wyraża być może także nadzieje pokładane przez środowisko żydowskie w nowej sytuacji politycznej (lat dziewięćdziesiątych).

W wyniku działań Fundacji Frenklów teren cmentarza przy ul. Walecznych został ostatecznie uporządkowany. Na część grzebalną przeniesiono ocalałe macewy z terenu miasta (obecnie znajdują się tam stele z Wieniawy i Głuska, a także jeden nagrobek z dawnego cmentarza wojennego z I wojny światowej przylegającego do nekropolii) oraz z Puław i Annopola ${ }^{150}$. W lipcu $1991 \mathrm{r}$. została zakończona odnowa cmentarza żydowskiego i budowa Izby Pamięci przy ul. Walecznych. W uroczystym otwarciu 23 lipca 1991 r. „wzięło udział czterdziestu Żydów z Izraela, Stanów Zjednoczonych, Belgii i Francji”. Obecni byli Sara i Manfred Frenklowie, sponsorzy tego przedsięwzięcia ${ }^{151}$. Wydarzenie to, jak wspomina Marian Wojtas odpowiedzialny za terminową realizację prac na cmentarzu, miało duże znaczenie dla władz miasta i jego wizerunku ${ }^{152}$.

Ogrodzenie odrestaurowanej części cmentarza składa się z trzystu stel-macew, które od strony zewnętrznej są stylizowane tak, aby symbolizowały zniszczenie i przemijanie. Od strony wewnętrznej natomiast można w nie wmontowywać tablice upamiętniające, co w późniejszych latach stało się częstą praktyką.

Powstała na terenie cmentarza Izba Pamięci to budowla o wysokości 10,5 m, która również nawiązuje kształtem do żydowskiego nagrobka:

${ }^{149}$ Przemówienie Symchy Wajsa, OBGTNN, Archiwum Symchy Wajsa, teczka VII, b.p.

${ }^{150}$ Informacja uzyskana od Andrzeja Trzcińskiego, który inwentaryzował zdeponowane na cmentarzu nagrobki.

${ }^{151}$ Wójcikowski, Wójcikowski, Kalendarium, s. 586; Jan Pleszczyński, Wspólna Izba Pamięci, „Gazeta Wyborcza” (24 lipca 1991), s. 1.

${ }^{152}$ Relacja Mariana Wojtasa, 20 marca 2018... 
powiększonej do ogromnych rozmiarów steli oraz tumby (skrzyni nagrobkowej), co symbolicznie należy łączyć z odnalezionym na terenie cmentarza nagrobkiem z 1939 r. ${ }^{153}$ Wewnątrz Izby Pamięci znajdują się wykonane z drewna dębowego elementy wyposażenia synagogi: aron-ha kodesz (w którym zgodnie z założeniem miała znajdować się Tora) i bima. Elementy metalowe wykonała pracownia kowalstwa artystycznego Elżbiety Kuskowskiej-Wnęk. We wnętrzu Izby mieści się także stała wystawa prezentująca dzieje lubelskich nekropolii żydowskich.

Symbolika tego upamiętnienia, projektu Stanisława Machnika, miała w zamyśle tworzyć pomost pomiędzy teraźniejszością i przeszłością, będąc - jak napisali autorzy broszury:

pomostem pomiędzy historią a teraźniejszością miasta Lublina, pomiędzy tętniącym życiem Żydów lubelskich przed II wojną światową a nowymi mieszkańcami Lublina, darem państwa Bass-Frenklów dla obecnych Lubliniaków oraz miejscem spotkań i modlitwy byłych mieszkańców tego miasta rozproszonych po całym świecie ${ }^{154}$.

Na nieogrodzonym terenie dawnej nekropolii (dziś po północnej stronie ul. Andersa) wzniesiono w czerwcu 1993 r. pomnik-ohel, w którego wnętrzu złożono urnę z prochami ofiar z byłego obozu na Majdanku, gdzie zamordowano część lubelskich Żydów ${ }^{155}$. Jeden z przedstawicieli władz miasta, który był odpowiedzialny za współpracę z Fundacją Sary i Manfreda Frenklów, wspominał, że początkowo środowiska żydowskie nie wyrażały zgody na utworzenie przejścia do pobliskiego osiedla przez teren północnej części cmentarza, jednak ostatecznie zgodziły się pod warunkiem przeniesienia grobów spod terenu wytyczonej ścieżki. Pochówki miały być przeniesione na obie strony wspomnianego traktu ${ }^{156}$.

Warto jeszcze wspomnieć o dokonanym przez Symchę Wajsa w 1992 r. upamiętnieniu wspomnianych 190 osób, których szczątki znaleziono na Majdanie Tatarskim. Pomnik nawiązuje do stylu dawnego ogrodzenia tego cmentarza. Na tablicach nagrobkowych wykonanych z granitu znajdują się napisy w języku hebrajskim i polskim (il. 9). Pomnik uzupełniało także swoiste lapidarium, na które składały się ustawione fragmenty nagrobków

${ }^{153}$ Opisowa charakterystyka rewaloryzacji cmentarza żydowskiego przy ul. Walecznych w Lublinie, OBGTNN, Materiały pozyskane od p. Stanisława Machnika, b.p.

${ }^{154}$ Ulotka o Izbie Pamięci Fundacji Sary i Manfreda Bass-Frenkel, OBGTNN, Archiwum Hanny Wyszkowskiej, teczka V, b.p.

${ }^{155}$ Kuwałek, Szlakiem pamięci..., s. 123; Wójcikowski, Wójcikowski, Kalendarium..., s. 577.

156 Relacja Mariana Wojtasa, 20 marca 2018... 


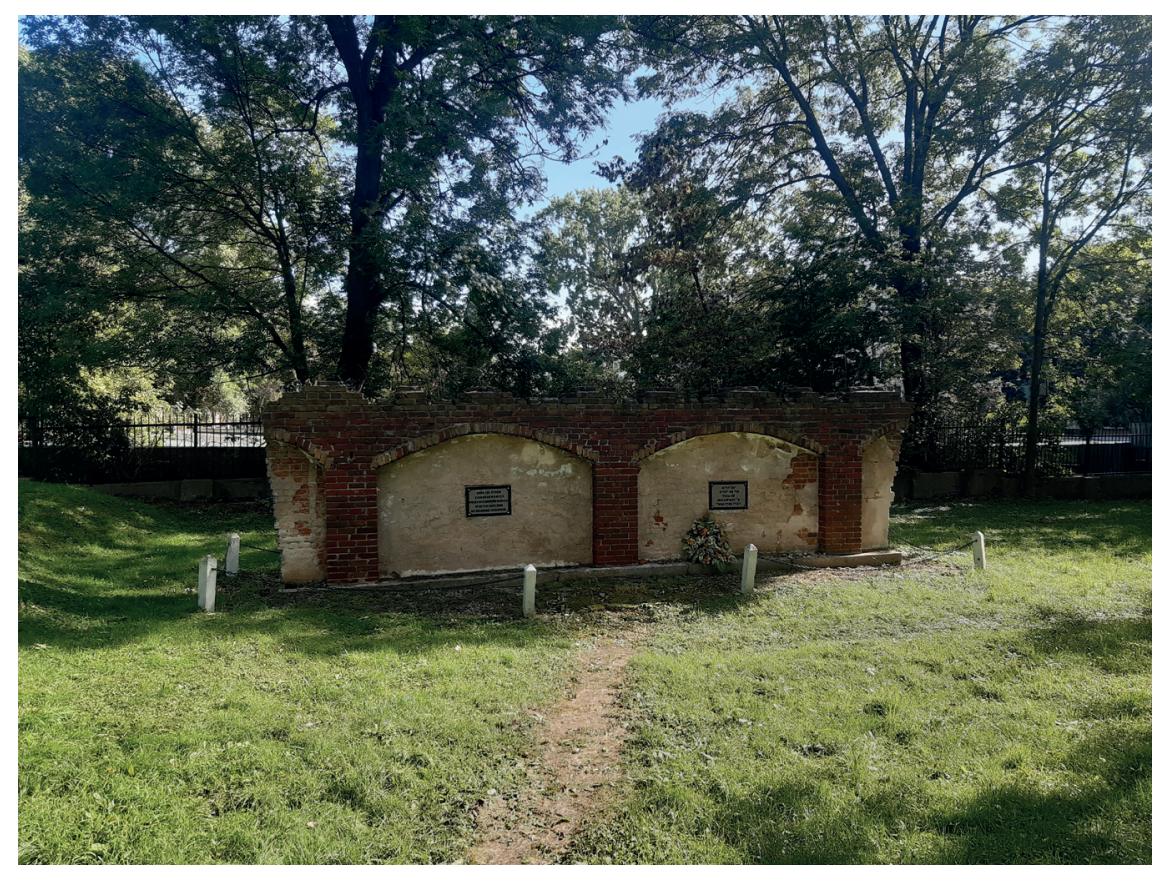

Il. 9. Pomnik Ofiar Getta na Majdanie Tatarskim; fot. Teresa Klimowicz, 2020.

i kamieni. Miało ono kształt wypełnionego białym żwirem prostokąta, pośrodku którego znajdowała się gwiazda Dawida usypana z czarnego żwiru. Po obu stronach lapidarium umieszczono dwie daty, 1942 i 1992, wykonane z czarnego żwiru ${ }^{157}$.

\section{Podsumowanie}

Nekropolia przy ul. Walecznych pozostaje nadal mało opracowanym cmentarzem lubelskim, a jej przedwojenna historia wciąż czeka na uzupełnienie. Powojenne dzieje cmentarza wskazują natomiast na próby utrzymania ciągłości pamięci i działalności kommemoratywnej wielu podmiotów. Można tu wyróżnić: polskie organizacje żydowskie (CKŻP, TSKŻ, Kongregacje Wyznaniowe), zagraniczne organizacje żydowskie (ziomkostwa oraz prywatne fundacje), organy władzy lokalnej (Wydział Gospodarki Komunalnej) czy lokalnych działaczy i grupy nieformalne. Mnogość tych 
podmiotów i niejasny podział ich kompetencji powodowały rozmycie odpowiedzialności za los żydowskich nekropolii.

Te nakładające się na siebie działania sprawiły, że cmentarz stał się nie tylko miejscem pochówku zmarłych bliskich, lecz także palimpsestem pamięci, obszarem świadczącym o skutkach wojny, związanych z Zagładą przemianach demograficznych społeczności żydowskiej, stał się przestrzenią odzwierciedlającą poczucie pustki u pozostałych w Lublinie Żydów. Wszystkie ingerencje w przestrzeń cmentarza dokonywane przez wspominane wcześniej podmioty, takie jak upamiętnienia, pochówki, prace budowlane, a także decyzje prawne, dewastacje i zaniechania, są w ujęciu interpretatywnej teorii kultury zapisami „znaczeń”. Ukazują one sposób konstruowania i wykorzystania przestrzeni żydowskiej. Sprawiają, że staje się ona palimpsestem, na którym napisane zostają znaczenia typowe dla nowego porządku społeczno-politycznego. Omawiany cmentarz przekształca się w pole performatywnej walki o podkreślenie swojej obecności przez zdziesiątkowaną społeczność żydowską, która jest uznawana i słyszalna w szerszym kontekście głównie jako element martyrologii wojennej.

Dla organów władzy administracyjnej cmentarz był przede wszystkim problemem własnościowym i prawnym, przeszkodą w rozwoju urbanizacyjnym, ewentualnie zasobem, który można było zaproponować okolicznym mieszkańcom. Z tej perspektywy jego symboliczna wartość ograniczała się do martyrologicznego wymiaru ofiar szeroko rozumianej II wojny światowej, gdyż obecność istniejącej społeczności żydowskiej z biegiem lat stawała się coraz mniej zauważalna. Aktywność kommemoratywna organizacji żydowskich widoczna jest zwłaszcza w powojennych latach czterdziestych, wyraźnie spada natomiast w latach pięćdziesiątych. Cmentarz ulega w tym czasie dewastacji i degradacji przy w zasadzie biernej postawie działaczy TSKŻ i lokalnej Kongregacji Wyznaniowej. Ignorowanie tradycji żydowskiej wpisywało się wówczas także w ogólną politykę sekularyzacji państwa. Chociaż władze centralne - jak zauważa także Yechiel Weizman - wyrażały (przynajmniej deklaratywnie) troskę o spuściznę Żydów polskich i umożliwiały praktyki religijne ${ }^{158}$, to jednak działanie władz lokalnych często odbiegało od zaleceń tego typu. Przykład omawianej nekropolii pokazuje, że również cmentarze oddane do użytku nie miały w całości zabezpieczonego terenu, a sam sposób ich użytkowania mógł budzić kontrowersje w środowiskach ortodoksyjnych. Cmentarz stał

158 Weizman, Unsettled Possession..., s. 5. 
się przedmiotem polityki nacjonalizacji własności i padał ofiarą niechętnego stosunku władz lokalnych przedkładających plany urbanizacyjne nad szacunek do zmarłych.

Funkcjonujący cmentarz nie wpisywał się też najpewniej w powszechne przekonanie o nieobecności Żydów w przestrzeni Lublina, uniemożliwiał bezproblemowe przyswojenie pojęcia mienia „pożydowskiego”, które można by swobodnie użytkować, nie napotykając większych protestów ze strony nieistniejącej (w założeniu) społeczności ${ }^{159}$. Wzmożona aktywność tej ostatniej w zakresie upamiętnień jest widoczna tuż po wojnie. Ma to zapewne związek nie tylko z bliskością czasową przebytej traumy, lecz także z pozycją samego Lublina w tym okresie. Fale emigracji związane $\mathrm{z}$ antysemityzmem i przemianami politycznymi sprawiają, że w latach pięćdziesiątych społeczność żydowska topnieje, a znikoma ilość źródeł nie pozwala na zarysowanie pełnego obrazu jej kondycji. We wczesnych latach sześćdziesiątych cmentarz staje się przedmiotem zainteresowania władz lokalnych - wyłącznie jednak w odniesieniu do czynnej jego części. Wydarzenia marcowe wydają się silnie oddziaływać na stan przestrzeni. Rok 1969 to nieprzypadkowo czas podziału omawianej nekropolii na dwie części, a więc praktycznie systematyczna dewastacja obszaru nieużytkowanego jako miejsce pochówku.

Dopiero wpisanie tej nekropolii (jak i innych) w politykę zagraniczną państwa i jego zewnętrzny wizerunek pozwoliło odmienić status cmentarza i sprawiło, że został uznany za wart zabezpieczania, dodany do rejestru zabytków i upamiętniony, a tym samym włączony do lokalnego dziedzictwa. Lata osiemdziesiąte XX w. przynoszą zmianę i pojawienie się indywidualnych inicjatyw podejmowanych w Lublinie przede wszystkim przez Symchę Wajsa oraz Fundację Sary i Manfreda Frenklów.

Historia cmentarza i jego upamiętnień obrazuje także politykę władz lokalnych i państwowych wobec społeczności żydowskiej w ogóle. Można powiedzieć, że jest ona typowa i zarazem poniekąd nietypowa. Z jednej strony wpisuje się w schemat charakterystyczny dla losu cmentarzy żydowskich: jego nieużytkowana część ulega profanacji i dewastacji, przeznaczona zostaje na inne cele jako teren zielony. $Z$ drugiej zaś strony część cmentarza jest użytkowana i traktowana jako teren grzebalny oraz pomnik martyrologiczny i jako taka stała się przedmiotem performatywnych zabiegów zarówno społeczności żydowskiej, jak i władz różnych szczebli. Sytuacja 
ta jest - jak należy przypuszczać - nie tyle nietypowa, ile mało zbadana ze względu na niewielką liczbę czynnych cmentarzy żydowskich w kraju ${ }^{160}$ i brak badań kulturoznawczych (a nawet historycznych) poświęconych specyfice tego typu miejsc.

\section{Cmentarz przy ul. Walecznych współcześnie}

Przedstawione materiały tworzą obraz niechcianego dziedzictwa w powojennej Polsce, pokazując, że cmentarze w swej istocie nie są traktowane jako pełnoprawne elementy przeszłości Polski, lecz raczej jako niewygodne obiekty przypominające o historycznych zaszłościach, wskazują na marginalizowany status tych miejsc jako niecmentarzy, których sakralny charakter łatwo pominąć, samą zaś przestrzeń uważać za możliwy do zagospodarowania zasób terenu.

Warto zatem zwrócić uwagę także na aktualną kondycję omawianej przestrzeni. Obecnie (rok 2020) teren cmentarza nadal podzielony jest na dwie części ruchliwą ulicą. Na stronie południowej (po południowej stronie al. Andersa) wydzielona została część czynna, którą zwrócono Gminie Wyznaniowej Żydowskiej w Warszawie. Część północna, nieczynna, została przejęta na własność przez Skarb Państwa i znajduje się obecnie pod zarządem Wydziału Gospodarowania Mieniem Urzędu Miasta Lublina. $\mathrm{Na}$ obu częściach cmentarza istnieje nadal architektoniczny projekt upamiętniający, ufundowany przez Sarę i Manfreda Frenklów, czynna zaś część nekropolii jest okazjonalnie udostępniana zwiedzającym za pośrednictwem lubelskiej filii Gminy Wyznaniowej Żydowskiej w Warszawie (klucz można pobrać w należącym do Gminy Wyznaniowej budynku dawnej uczelni rabinackiej zamienionej na hotel „Ilan”). Nieczynna część cmentarza, choć także wpisana do rejestru zabytków, nadal użytkowana jest jako teren zielony, na który okoliczni mieszkańcy regularnie wyprowadzają psy (il. 10).

${ }^{160}$ Obecnie na terenie Polski jest kilkanaście czynnych cmentarzy żydowskich (dane za: Wirtualny Sztetl [dostęp: 30 września 2020]) znajdujących się m.in. w następujących miejscowościach: Bielsko-Biała, Bytom, Dzierżoniów, Gliwice, Katowice, Kraków, Lublin, Nowy Sącz, Przemyśl, Szczecin, Wałbrzych, Warszawa, Wrocław i Żary. 


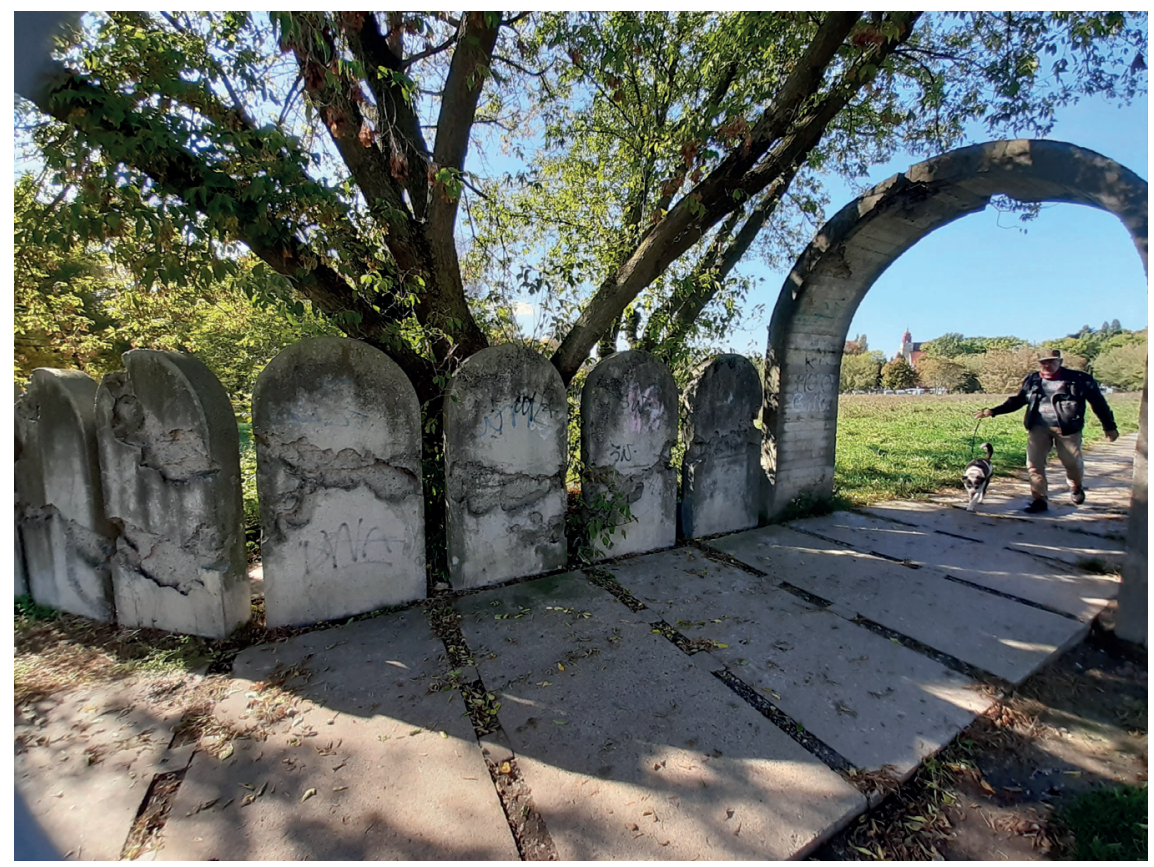

Il. 10. Południowa, nieczynna część cmentarza żydowskiego od strony al. Władysława Andersa; fot. Teresa Klimowicz, 2020.

\section{Bibliografia}

\section{1. Źródła archiwalne}

Archiwum Akt Nowych, Urząd ds. Wyznań, sygn. 13/433, 132/264, 132/272.

Archiwum Archidiecezji Częstochowskiej, Zgony za lata 1944-1945, poz. 126, 158, 163, 175, https://FamilySearch.org [dostęp: 6 stycznia 2020].

Archiwum Litmana Romana

Archiwum Państwowe w Lublinie

Rada Żydowska w Lublinie w latach 1939-1942, sygn. 6/177, 6/179.

Urząd Wojewódzki Lubelski (Zespół 1079), Wydział ds. Wyznań, sygn. 353, $354,361$.

Wojewódzkie Zrzeszenie Gospodarki Komunalnej, sygn. 314. Archiwum Wojewódzkiego Urzędu Ochrony Zabytków w Lublinie

Marciszuk Krzysztof, Cmentarz żydowski przy ul. Walecznych w Lublinie, 1987, sygn. 1239.

Sygowski Paweł, Karta ewidencyjna cmentarza wojskowego przy ul. Walecznych / ul. J. Kuronia, nr 154, Lublin 2019. 
Archiwum Żydowskiego Instytutu Historycznego

„Biuletyn Żydowskiej Agencji Prasowej” 1944-1949, sygn. 354.

Centralna Żydowska Komisja Historyczna, 303/20, sygn. 114.

Towarzystwo Społeczno-Kulturalne Żydów w Polsce, sygn. 325/217.

Wojewódzki Komitet Żydowski w Lublinie, sygn. 355/4.

Ośrodek „Brama Grodzka - Teatr NN”

Archiwum Machnika Stanisława.

Archiwum Przeciechowskiego Tomasza, Dokumentacja Fundacji Sary i Manfreda Frenklów.

Archiwum Wajsa Symchy, teczki VII i X.

Archiwum Wyszkowskiej Hanny, teczka V.

Kolekcja ikonograficzna Kligera Józefa.

Relacja Wajsbrota Morrisa, 29 listopada 2010, rozmawiał Tomasz Czajkowski, red. Maria Radek.

Relacja Wojtasa Mariana, 20 marca 2018, rozmawiał Tomasz Czajkowski.

\section{2. Źródła opublikowane}

„Gazeta Lubelska” (15 grudnia 1946).

„Gazeta Wyborcza” (24 lipca 1991).

Górniewicz Czesław, Wspomnienia z okupacji niemieckiej. Pamiętnik więźnia Zamku Lubelskiego, Lublin 2016.

„JTA Daily News Bulletin” 1965, 1967.

„Kol Lublin” (1976), nr 11.

Księga pamięci żydowskiego Lublina, wstęp, wybór i oprac. Adam Kopciowski, Lublin 2011.

„Kurier Lubelski” 1957-1989.

Okólnik nr 3 z 6 lutego 1945 roku o tymczasowym uregulowaniu spraw wyznaniowych ludności żydowskiej, Dziennik Urzędowy Ministerstwa Administracji Publicznej nr 1 z 1945 r.

„Sztandar Ludu” 1945-1989.

Urban Kazimierz, Cmentarze żydowskie, synagogi $i$ domy modlitwy w Polsce $w$ latach 1944-1966 (wybór materiałów), Kraków 2006.

Ustawa z dnia 31 stycznia 1959 r. o cmentarzach i chowaniu zmarłych, Dz.U. 1959, nr 11, poz. 62.

\section{Opracowania}

Bednarek Małgorzata, Sytuacja prawna cmentarzy żydowskich 1944-2019, KrakówBudapeszt 2020.

Bielawski Krzysztof, Zagłada cmentarzy żydowskich, Warszawa 2020.

Canin Mordechaj, Przez ruiny i zgliszcza. Podróż po stu zgładzonych gminach żydowskich w Polsce, tłum. Monika Adamczyk-Garbowska, Warszawa 2018.

Datner Helena, Po Zagładzie. Społeczna historia żydowskich domów dziecka, szkót, kót studentów w dokumentach Centralnego Komitetu Żydów w Polsce, Warszawa 2016. 
Dziobek-Romański Jacek, Cmentarze - zarys regulacji historycznych, prawnych $i$ kanonicznych, „Rocznik Historyczno-Archiwalny” 13 (1999).

Geertz Clifford, Opis gęsty - w strone interpretatywnej teorii kultury, [w:] Badanie kultury. Elementy teorii antropologicznej, red. Marian Kempny, Ewa Nowicka, Warszawa 2005.

Grabski August, Centralny Komitet Żydów w Polsce (1944-1950). Historia polityczna, Warszawa 2015.

Jagodzińska Agnieszka, Pomiędzy. Akulturacja Żydów Warszawy w drugiej połowie XIX wieku, Wrocław 2008.

Jeremicz Jacek, Klimowicz Teresa, Organizacja życia żydowskiego po II wojnie światowej, „Scriptores” (2019), nr 46.

Kendziorek Piotr, Program i praktyka produktywizacji Żydów polskich w działalności CKŻP, Warszawa 2016.

Klimowicz Teresa, Lubelski Oddziat Towarzystwa Społeczno-Kulturalnego Żydów w Polsce w latach 1950-1968, „Scriptores” (2019), nr 46.

Kolbuszewski Jacek, Cmentarz jako tekst kultury, „Odra” (1981), nr 11.

Kopciowski Adam, Wos hert zich in der prowinc? Prasa żydowska na Lubelszczyźnie i jej największy dziennik „Lubliner Tugblat”, Lublin 2015.

Kopciowski Adam, Zajścia antyżydowskie na Lubelszczyźnie w pierwszych latach po II wojnie światowej, „Scriptores” (2019), nr 46.

Kowalczyk Irena, Lubelskie nekropolie, Lublin 2019.

Kubiszyn Marta, Niepamięć - postpamięć - wspótpamięć. Zagłada lubelskich Żydów jako przedmiot kultury pamięci, Lublin 2019.

Kuwałek Robert, Szlakiem pamięci, [w:] Robert Kuwałek, Wiesław Wysok, Lublin. Jerozolima Królestwa Polskiego, Lublin 2001.

Matyjaszek Konrad, Produkcja przestrzeni żydowskiej w dawnej i współczesnej Polsce, Kraków 2019.

Minars Esther, A Lublin Survivor: Life Is Like a Dream. As Told by Eva Eisenkeit, Brighton 2019.

Nastęstwa zagłady Żydów. Polska 1944-2010, red. Monika Adamczyk-Garbowska, Feliks Tych, Lublin 2011.

Ożóg Kazimierz S., Pomniki Lublina, Lublin 2014.

Radzik Tadeusz, Lubelska dzielnica zamknięta, Lublin 1999.

Sommer Schneider Anna, Sze'erit hapleta. Ocaleni z Zagłady. Działalność American Jewish Joint Distribution Committee w Polsce w latach 1945-1989, Kraków 2014.

Sygowski Paweł, Cmentarze żydowskie Zamojszczyzny - stan badań, stan zachowania, uwagi konserwatorskie, [w:] Żydzi w Zamościu i na Zamojszczyźnie. Historiakultura - literatura, red. Weronika Litwin, Monika Szabłowska-Zaremba, Sławomir Jacek Żurek, Lublin 2012.

Symcha Wajs (1911-1999), [w:] Sylwetki Żydów lubelskich. Leksykon, red. Adam Kopciowski i in., Lublin 2019.

Szaynok Bożena, Komuniści w Polsce (PPR/PZPR) wobec ludności żydowskiej (1945-1953), „Pamięć i Sprawiedliwość” (2004), nr 2.

Tomczyk Józef, Rada Żydowska w Lublinie 1939-1942 - organizacja, działalność i pozostałość aktowa, [w:] Żydzi w Lublinie. Materiały do dziejów społeczności żydowskiej Lublina, t. 1, red. Tadeusz Radzik, Lublin 1995. 
Trzciński Andrzej, Cmentarz żydowski w Hrubieszowie. Nagrobki niewykorzystane do pomnika-lapidarium i zakopane obok lapidarium, Lublin 1999.

Trzciński Andrzej, Świadkiem jest ta stela. Stary cmentarz żydowski w Lublinie, Lublin 2017.

Urban Kazimierz, Zagadnienie pożydowskich synagog $i$ cmentarzy $w$ Polsce $w$ latach 1945-1956 (zarys problematyki), „Zeszyty Naukowe Akademii Ekonomicznej w Krakowie" (2005), nr 692.

Wajs Karolina, Wajs Symcha, Fakty $i$ wydarzenia z życia lubelskich Żydów, Lublin 1997.

Weizman Yechiel, The Sacralization and Secularization of Jewish Cemeteries in Poland, [w:] Jews and Non-Jews: Memories and Interactions from the Perspective of Cultural Studies, red. Lucyna Aleksandrowicz-Pędich, Jacek Partyka, Warszawa 2014.

Weizman Yechiel, Unsettled Possession: The Question of Ownership of Jewish Sites in Poland after the Holocaust from a Local Perspective, „Jewish Culture and History" 18 (2017), nr 1.

Wodziński Marcin, Groby cadyków w Polsce. O chasydzkiej literaturze nagrobnej i jej kontekstach, Wrocław 1998.

Wójcikowski Grzegorz, Wójcikowski Włodzimierz, Kalendarium, [w:] Tadeusz Radzik, Wiesław Śladkowski, Grzegorz Wójcikowski, Włodzimierz Wójcikowski, Lublin. Dzieje miasta. T. 2: XIX i XX wiek, Lublin 2000.

Zieliński Konrad, W cieniu synagogi. Obraz życia kulturalnego społeczności żydowskiej Lublina w latach okupacji austro-węgierskiej, Lublin 1998.

\section{4. Źródła internetowe}

Baza danych nagrobków cmentarzy żydowskich $w$ Polsce, Fundacja Dokumentacji Cmentarzy Żydowskich w Polsce, https://cemetery.jewish.org.pl/list/c_56 [dostęp: 4 listopada 2019].

Bielawski Krzysztof, Lublin - nowy cmentarz żydowski, www.kirkuty.xip.pl/lublinnowy.htm [dostęp: 25 stycznia 2020].

Nowy cmentarz żydowski w Lublinie, https://sztetl.org.pl/pl/miejscowosci/l/264-lublin [dostęp: 25 stycznia 2020].

Santarek Stanisław, Rzymskokatolicki cmentarz przy ulicy Unickiej w Lublinie, http:// unicka.cmentarz.lublin.pl/historia/ [dostęp: 12 października 2019].

Szyc Nuchym, Płacz zamiast modlitwy, 1988, oprac. Łukasz Jasina, 2006, OBGTNN, http://biblioteka.teatrnn.pl/dlibra/Content/9626/Placz_zamiast_modlitwy.pdf [dostęp: 5 listopada 2019].

Teresa Klimowicz Instytut Nauk o Kulturze, UMCS t.klimowicz@umcs.pl 